\title{
Negative health outcomes associated with food insecurity status in the United States of America: A systematic review of peer-reviewed studies
}

Daniel J. Arenas ${ }^{1,5}$, Sara Zhou ${ }^{2,5}$, Arthur Thomas ${ }^{1,5}$, JiCi Wang ${ }^{2,5}$, Gilberto Vilá-Arroyo ${ }^{3,5}$, and Katie Bash $^{4,5}$

\footnotetext{
${ }^{1}$ Perelman School of Medicine, University of Pennsylvania, Philadelphia, Pennsylvania 19104, United States of America

${ }^{2}$ College of Arts and Sciences, University of Pennsylvania, Philadelphia, Pennsylvania 19104, United States of America

${ }^{3}$ School of Podiatric Medicine, Temple University, Philadelphia, Pennsylvania 19107, United States of America

${ }^{4}$ Social Work and Practice, University of Pennsylvania, Philadelphia, Pennsylvania 19104, United States of America

${ }^{5}$ United Community Clinic, 4159 West Girard Avenue, Philadelphia, Pennsylvania 19104, United States of America
}

KEYWORDS: Food insecurity, health disparities, systematic review, social determinants of health

\begin{abstract}
Introduction: Social determinants of health, such as food security, are an important target for health providers, particularly in the care of patients from underserved populations, including the uninsured and socially marginalized. Preliminary research has shown that food insecurity status (FIS) is associated with negative health outcomes.

Objective: We aim to present a concise, yet comprehensive resource that lists the health outcomes associated with FIS. This guide is meant to provide innovative health providers with the tools needed to justify the importance of using FIS screening and treatment as a preventive medicine intervention.

Methods: We conducted a systematic review of peer-reviewed manuscripts that studied FIS in the United States of America (USA) and at least one health outcome. We searched PubMed, Embase, Web of Science, and Scopus and had multiple reviewers examine each abstract and manuscript. We only retained peer-reviewed studies that contained USA data, directly measured FIS, and directly compared FIS to a health outcome.
\end{abstract}


Results: The initial search yielded 1,817 manuscripts. After screening abstracts for duplicates and inclusion criteria, a total of 117 manuscripts were retained and fully examined. Several manuscripts showed significant association between FIS and neurologic, cardiac, endocrine, and pulmonary health outcomes. Studies in the USA population show robust associations between FIS and poor mental health (including depression, anxiety, sleep disorders, impaired cognitive functioning, and epilepsy), metabolic syndrome, hyperlipidemia, greater risk for bone fracture in children, higher risk of end-stage renal disease in patients with chronic kidney disease, self-reported poor health, and higher mortality in patients with the human immunodeficiency virus. Though other literature reviews show positive associations between FIS and health outcomes such as diabetes, body mass index, and hypertension, our systematic review showed mixed results.

Conclusions: FIS leaves underserved populations at risk for negative health outcomes. More research should be done to examine the effects of FIS alleviation as a preventative medicine intervention.

\section{Introduction}

Patients who live below the federal poverty line and hold minority-group status are more likely to have poorer outcomes in chronic yet common conditions such as diabetes(1), hypertension(2-4), hypercholesteremia(5-7), osteoporosis(8,9), and depression(10,11). Underserved populations also have a greater prevalence of poorer outcomes in complications such as kidney disease(12-14), neuropathy(15), strokes(16), cardiac failure(17,18), and atherosclerosis(19), as well as outcome imbalances in cancer diseases such as breast cancer, lung cancer, and colon cancer(20,21). Since preventive medicine can significantly reduce the burden of these diseases, increasing its access to impoverished or neglected populations is paramount(22).

Some innovative health-provider models target preventive medicine services to traditionally underserved populations(23,24). Provider models such as student-run clinics (SRCs) and mobile health 
clinics aim to increase availability and affordability to patients who fall within this category(25). Evidence suggests that the efforts of SRCs have resulted in high patient and provider satisfaction(26,27), as well as significant health and economic impacts(28). The interdisciplinary nature(23) of SRCs allows them to focus on services that alleviate the strain that a lack of affordable housing, food insecurity, substance addiction, and other conditions place on individuals. In order to enhance their services, it is advisable to incorporate socioeconomic questions and interventions into the general healthcare protocol utilized by SRCs and other innovative health providers.

It is important to validate why socioeconomic interventions belong in a health care setting. Resource allocation is an important concern because providers have limited capabilities and a limited amount of time with patients. Another concern is that patients deserve to know why health providers are screening for socioeconomic risks in a healthcare setting. Inquiries about food insecurity and housing stability are personal and potentially difficult to answer and are just two examples of the types of questions patients may not anticipate upon visiting a health clinic. Providers must be able to explain in a concise and clear matter the importance of socioeconomic interventions, as they pertain to the patient's health.

A common socioeconomic intervention in innovative health provision is the alleviation of FIS. All patients are screened for FIS and those who are found to be at risk are given information about local food assistance programs, food banks, and other resources. One important justification of this intervention is that several studies show that FIS is associated with negative health outcomes such as depression and diabetes(11,29). However, there are many studies but no systematic consolidation of all the health outcomes associated (and not associated) with FIS. Our rationale for conducting this review is that there have been some broad reviews of the association between FIS and various health outcomes, but they are not systematic(30-33), and they do not include insignificant associations. Furthermore, existing systematic reviews mainly focus on specific healthcare outcomes, and many non-physiological 
measurements [i.e. adherence for anti-retroviral therapy (ART) medication]. The objective of this study is to provide a resource in the form of a review, which consolidates the health outcomes (positive or negative) directly associated (or not associated) with FIS in the USA population.

Clearly, condensing and analyzing these studies would allow providers to make more accurate and compelling arguments when justifying the need for FIS screenings and/or interventions in clinical settings. This justification is important, whether it is aimed at management, donors, the community, or patients themselves.

\section{Methods}

\section{Databases Search}

Information sources were the four databases: PubMed, Scopus, Web of Science, and Embase. We searched for abstracts that included the three concepts: Health outcomes, FIS, and USA. Search terms were tailored for each database and the details of the electronic search strategy are offered in S1 of the supplementary documents. Duplicates were removed using RefWorks and by subsequent manual inspection. Table 1 shows an outline of the results. The search was conducted on September- $4^{\text {th }}-2017$ and yielded 1,817 abstracts.

\section{Abstract Exclusion}

We used the program Abstrackr(34) to conduct the abstract exclusion process. A study was deemed relevant if it satisfied all the following eligibility criteria: 1) The study contained USA data, 2) it was peer-reviewed, 3) it was quantitative, 4) it measured FIS, and 5) it studied a health outcome. We decided to exclusively use manuscripts that contain data from the USA because our target audience consists of innovative health providers and social workers who reach vulnerable and underserved 
populations in this country. Only articles written in English were considered, and all publication dates were accepted.

Since health outcome is a broad definition that merits discussion among the reviewers, we first ran a pilot of the study selection process. During which, four investigators reviewed the same 200 abstracts with three possible options: "inclusion", "exclusion”, and "maybe". The pilot was also helpful to assess agreement in the other criteria areas. We counseled reviewers to conduct a sensitive search: they would keep the study if it was not clear from the abstract that a criterion was met, and the reviewers were made aware that the next step, reading the text manuscript, would offer an opportunity to exclude unclear abstracts. After the abstract exclusion pilot, 76 percent of the 200 abstracts had complete ratings-agreement between the four graders. The inter-rater reliability of the four graders was quantified using a Fleiss kappa value of $0.49[0.32,0.66]$, which yielded moderate agreement. The disagreements in the pilot exclusion were reviewed with a fifth new reviewer, and then multiple reviewers met to discuss these disagreements. The discussion resulted in choosing that food environment would not be considered as food insecurity, and that we would not treat diet quality nor food environment as health outcomes. We also decided to keep self-reported physical and mental health, and cognitive development as health outcomes. From the discussion, we also decided to disregard manuscripts that solely linked food environment and poor health outcomes. FIS and poor food environment are linked, but they are not equal. In this manuscript we decided to focus on FIS because it is more straightforward to screen a patient for FIS than for their food environment. 
Figure 1. Flow of identification of manuscripts for the systematic review.

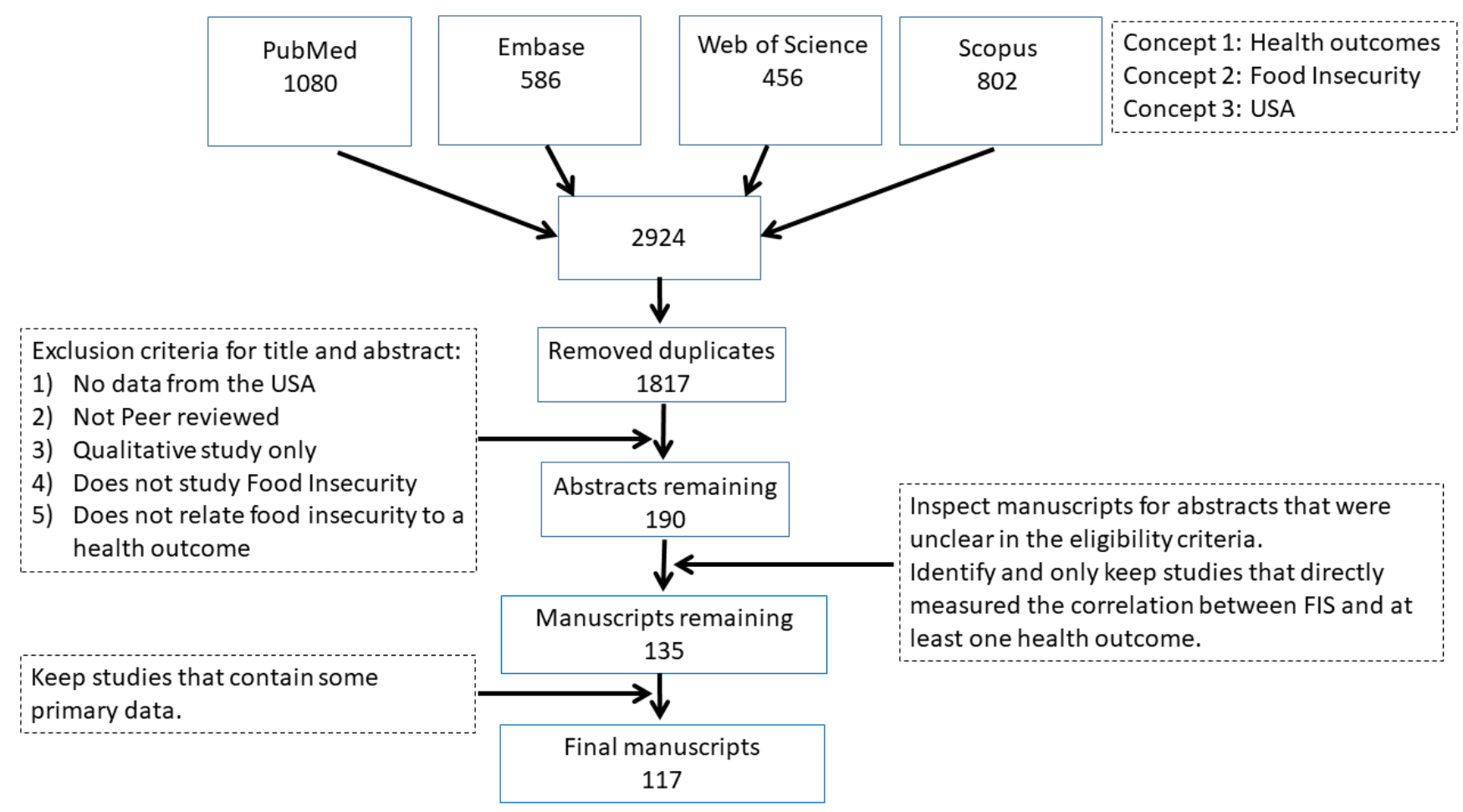

After the pilot and subsequent discussion, we randomly distributed the remaining 1,617 abstracts to four reviewers in such a way that at least two reviewers examined each abstract. Ninety-four percent of the abstracts had complete-agreement between the two raters, and the Fleiss kappa inter-reliability was 0.62 [CI: 0.55, 0.69], suggesting 'substantial agreement'. At the end, we retained 190 abstracts out of the original 1,817 .

\section{Manuscripts examination}

This step only included the 190 abstracts that remained after the previous step. We randomly distributed the 190 abstracts to five reviewers so that at least two reviewers examined each manuscript. Reviewers read the text of the manuscript to fulfill two goals: one, ascertain that the manuscript satisfied the inclusion criteria (which may have not been clear from the abstract). In this step reviewers also had to identify and exclude abstracts from poster sessions that did not have full text associated with it. At this point, we also removed duplicates that were missed by the automated program earlier. 
The second, and possibly the most challenging, step of the manuscript examination was identifying studies that directly measured the correlation between FIS and a health outcome. The objective was to approve only the papers that investigated the possibility of a direct association between FIS and a health outcome. This research project defines "investigation of direct association" as having directly measured the correlation between FIS and a health outcome. This means that papers that correlate FIS to a health outcome via another variable (i.e. food prices, food environment) are not acceptable. It was equally valid if the direct correlation was discussed in the text, or if data was presented in a table comparing the prevalence of the health outcome with or without FIS. It was clearly communicated to all reviewers that positive and negative results (significant or non-significant) were equally important.

There was $85 \%$ agreement between the reviewers in exclusion of the manuscripts. The two-rater kappa was 0.60 . We automatically excluded the 32 abstracts for which both reviewers agreed were not appropriate. We then maximized the sensitivity of the search by further exploring (by a third reader) manuscripts for which only one reviewer voted to exclude, then 15 more manuscripts were excluded by the third reviewer. After this point, reviewers met to discuss disagreements and to revisit which health outcomes would be included. The conclusion was that studies that measured smoking rate, illegal drug use rate, and medication adherence were excluded if they did not present another health outcome [such as chronic obstructive pulmonary disease (COPD) exacerbation, or neurologic complications]. Eight studies were subsequently removed.

The 18 review studies found(31-33,35-50) were examined to see if they provided primary data, otherwise they were discarded. The final number of manuscripts was 117. 


\section{Data extraction and organization into systems}

The data collection process for the final 117 manuscripts consisted of two reviewers independently reading each manuscript and cataloguing the health outcomes that were measured and directly compared to the FIS measurement. The main summary measures sought in each manuscript were the health outcome studied and whether the association with FIS was significant or not. These associations were obtained from tables of odd ratios, statements in the text, $p$-values, and/or confidence intervals. We concluded that the paper showed significant association based on the $p$-values and their confidence interval, and we noted if there was a discrepancy with the text. Other data items extracted from each manuscript were: The methods for measurement of FIS and health outcomes, the populations studied, and the study size. Each health outcome was separated into the following categories: Brain and Behavior, Cardiovascular, Endocrine, Infectious Disease, Pulmonology, Renal, Musculoskeletal, and General Health. Some manuscripts related multiple health outcomes measurements to FIS and therefore the studies were mentioned more than once. All manuscripts and their summary measures are presented for each health outcome and synthesized in tables in the Results section.

\section{Results and Discussion}

Figure 1 shows the number of studies screened along with the intermediate results and the final result of 117 studies. All 117 manuscripts were published after 1999, and the results clearly show (Figure 2) that the scientific community has experienced a sharp increase in the interest of the health effects of FIS.

For each health outcome, the results are synthesized in a table that is presented in the main text, or $\mathrm{S} 2$ of the supplementary documents, that lists for each study the following: population characteristics, type of measurement for both FIS and the healthcare outcome, study size, and citations. 
The two most common surveys that were used to measure FIS were the United States Department of Agriculture Food Security Survey Module (USDA FSSM) and the National Health and Nutrition Examination Survey (NHANES). The USDA FSSM survey is sometimes referred by different names such as US Adult Food Security Survey Module, Bickel's Household Food Security Survey, USDA Household Food Security Scale, among others. The survey consists of screeners asking the individual questions about the prevalence of FIS and hunger in their household within the span of a year. The NHANES is a general population survey that combines information from interviews and physical examinations and includes information about an individual's nutrition and health status. Another common FIS and health outcome measurement tool were custom surveys conducted during patient interviews.

Figure 2. Publications by year of the final 117 studies.

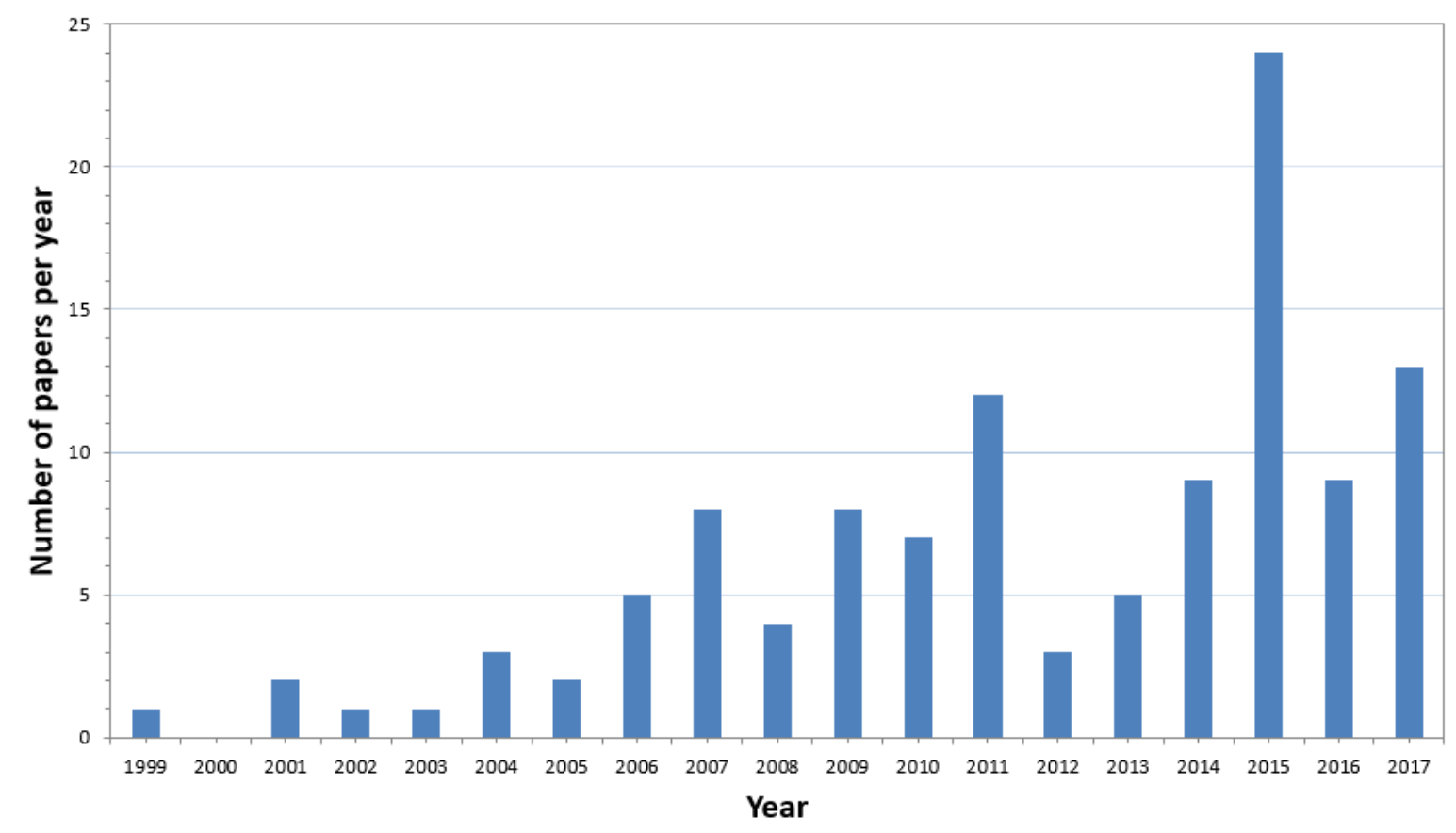

Legend: Of the final 117 studies, all were published after 1999. The graph shows the increasing interest in the health repercussions of FIS in the last decades. 


\section{Brain and Behavior}

Anxiety

Out of the 117 manuscripts, there were seven (Table 1) with data that directly compares stress/anxiety to FIS. All of the articles found a significant association between the two variables. The studies used a diverse group of questionnaires for measuring FIS and anxiety, with one study directly measuring cortisol levels. The effect of FIS on anxiety was shown in preschool children(51), pregnant women(52,53), general public visiting the emergency department (ED)(54), diabetic patients(55,56), Hispanic adults(57), and college freshmen(58).

The mechanism between food insecurity and anxiety is straightforward: members of the family worry about the household's family food supply(58,59). This is not only unfortunate for the obvious impact on the patient and family, but to society in general, since anxiety has a well-known economic burden associated with both medical and general productivity costs(60).

\section{Table 1. Anxiety and FIS}

\begin{tabular}{|l|l|l|l|l|l|l|}
\hline Year & Authors & $\begin{array}{l}\text { FIS } \\
\text { measurement }\end{array}$ & HO measurement & $\begin{array}{l}\text { Population } \\
\text { characteristics }\end{array}$ & $\begin{array}{l}\text { Study } \\
\text { size }\end{array}$ & $\begin{array}{l}\text { Significant } \\
\text { association with } \\
\text { FIS? }\end{array}$ \\
\hline 2002 & $\begin{array}{l}\text { Weinreb et } \\
\text { al.(51) }\end{array}$ & $\begin{array}{l}\text { 7-item custom } \\
\text { questions }\end{array}$ & $\begin{array}{l}\text { NHIS Child Behavior } \\
\text { Checklist }\end{array}$ & $\begin{array}{l}\text { Preschool children } \\
\text { in MA }\end{array}$ & 152 & Yes \\
\hline 2006 & $\begin{array}{l}\text { Laraia et } \\
\text { al.(52) }\end{array}$ & USDA FSSM & $\begin{array}{l}\text { Spielberger's Trait } \\
\text { Anxiety Inventory }\end{array}$ & Pregnant women & 606 & Yes \\
\hline 2011 & $\begin{array}{l}\text { Sullivan et } \\
\text { al.(54) }\end{array}$ & USDA FSSM & Custom question & $\begin{array}{l}\text { Boston ED } \\
\text { patients }\end{array}$ & 496 & Yes \\
\hline 2015 & $\begin{array}{l}\text { Becerra et } \\
\text { al.(57) }\end{array}$ & $\begin{array}{l}\text { 3-item custom } \\
\text { questions }\end{array}$ & Kessler 6-scale & $\begin{array}{l}\text { Low income } \\
\text { Hispanic adults }\end{array}$ & 10,966 & Yes \\
\hline 2015 & $\begin{array}{l}\text { Borders et } \\
\text { al.(53) }\end{array}$ & USDA FSSM & ACTH levels & Pregnant women & 112 & Yes \\
\hline & $\begin{array}{l}\text { Bermudez- } \\
\text { Millan et } \\
\text { al.(56) }\end{array}$ & $\begin{array}{l}\text { 6 items from } \\
\text { USDA FSSM }\end{array}$ & $\begin{array}{l}\text { PHQ, Problem Areas in } \\
\text { Diabetes Questionnaire }\end{array}$ & Diabetic adults & 121 & Yes \\
\hline 2016 & $\begin{array}{l}\text { Darling et } \\
\text { al.(58) }\end{array}$ & USDA FSSM & DASS & College freshmen & 98 & No \\
\hline
\end{tabular}


NHIS: National Health Interview Survey

MA: Massachusetts

ACTH: Adrenocorticotrophic hormone

PHQ: Patient Health Questionnaire

DASS: Depression, Anxiety, and Stress Scale

\section{Cognitive Development}

Out of six papers reviewed(51,61-65), five manuscripts reveal a significant association between FIS and cognitive impairment (Table S2-1). This association is observed among USA children(51,62), Mexican migrant farm workers' children(61), Puerto Rican adults(65), and older adults(64). Cognitive development is measured through various tests, including surveys, in-person interviews, the MiniMental State Examination (MMSE), the 22-item Adult Lifestyles and Function Interview Mini-Mental State Examination (ALFI MMSE), and Parents' Evaluations of Developmental Status (PEDS).

A rather surprising result from the studies reveals that the association between FIS and cognitive impairment seems to not only affect children but also adults, and even older adults. For example, in a study with Mexican migrant farm workers' children, food insecure households are significantly more likely to have at least one child suffering from a physician-diagnosed learning disability(61). In addition, a longitudinal study with Puerto Rican subjects ages 40-75 in the Boston region demonstrates a 2-year decline in global cognitive function in association with FIS at the baseline level(65). Lastly, a recent nationally representative study of kindergarten children shows that FIS results in lower hyperactivity, conduct problems, and lower reading and math scores(66).

The diverse range of age cohorts and methodologies in these studies suggest a robust correlation between FIS and cognitive impairment. Further investigation in the directionality of this relationship may provide greater insights. 


\section{Depression}

Thirty manuscripts studied the association between FIS and depression(51,52,55,56,58,59,61,63,64,67-87), and twenty-eight of them show a significant association (Table S2-2). The association between FIS and depression is strong and is demonstrated in the general public(68), college students(58,59,83), minorities(55,76,80), geriatric patients(64), migrant farm workers(61), diabetic(55,56,87), and patients with the human immunodeficiency virus (HIV)(75,79,87). Additionally, FIS increases the risk of prenatal depression(52,72,73), and increases depression rates later in life for individuals who experience FIS as children(51).

The association was robust to the choice of depression measurement used by the studies. This included several questionnaires such as the Center for Epidemiological Studies Depression Scale (CESD)(88,89), Patient Health Questionnaire (PHQ)(90,91), Geriatric Depression Scale (GDS)(92,93), Depression Anxiety and Stress Scale (DASS)(94), as well as custom questions. These studies also used different questionnaires for FIS measurement and were conducted in several locations across the USA.

The association between FIS and depression is important, and worth the multitude of studies, because the effects of depression are devastating and well-documented(95). Depression increases the risk of suicide(96), and affects society with absenteeism and reduced productivity at work(97). In geriatric patients, depression can be detrimental to functioning and self-care, and it is as detrimental as heart and lung conditions $(98,99)$. Depression during pregnancy is damaging to fetal health, increases the risk of pre-term delivery, and results in poorer maternal practices after birth(100). In all, the effects of depression are detrimental to all of society; in 1990 it was estimated that depression created an economic burden of over $\$ 40$ billion in the USA(95). Although it is not the scope of this paper, future work can be done to estimate the cost efficiency of food insecurity interventions and the burdens that could be prevented on depression alone. 


\section{Epilepsy}

A recent manuscript represents the first comprehensive study to investigate the relationship between FIS and epilepsy among USA children(101) (Table S2-3). The researchers review the electronic health record data of children ages 2-17 years old, who receive care from an academic pediatric hospital. The measured health outcomes are divided into two portions: 1) acute care utilization and 2) assessments of quality-of-life and epilepsy medication side effects. The former is determined by emergency department visits and hospitalizations, and the latter is measured via formalized questionnaires: the health-related quality-of-life (HRQOL) and Pediatric Epilepsy Side-Effects Questionnaire (PESQ), which evaluates the side effects of anti-epileptic drugs (AEDs). Overall, the results show that $14 \%$ of the children in the study suffered from FIS. The results also found that children who experience FIS experience greater utilization of healthcare facilities, lower quality of life, and higher AED side effects(101).

This study is significant because it demonstrates a positive correlation between epileptic symptoms and FIS. Lastly, the results expand the notion that FIS may be particularly influential among children with long-term health management needs. Epilepsy epitomizes such a need and represents an ideal area for further research.

\section{Sleep}

A significant association is observed between FIS and poor sleep in all seven manuscripts reviewed(54,56,102-106) (Table S2-4). This correlation is demonstrated among USA veterans(104,105), diabetic Latinos(56), ED patients in Boston(54), as well as the general adult population in the USA $(102,103,106)$. In these studies, sleep quality, duration, complaints, insomnia, and latency are measured through subjects' self-reported surveys(54,56,103,104,106). A 2013 study conducted by Grandner et al. measured a more comprehensive breadth of symptoms linked to common 
sleep disorders like insomnia and sleep apnea: sleep latency, difficulty falling and staying asleep, waking in the morning, non-restorative sleep, and sleepiness during the day, snorting or gasping, and snoring(102).

This positive association between FIS and poor sleep is important because sleep defects are often linked to many other health problems, including; injury, cardiovascular disease, obesity, diabetes, hypertension, general poor health, and mental health issues(105). Moreover, FIS afflicts more adverse effects on sleep than any other measured sociodemographic or socioeconomic variable(102). This finding demonstrates that FIS holds unique effects on sleep symptoms and warrants more investigation. Furthermore, Bermudez et al.'s 2016 study of diabetic Latinos reveals that the direct relationship between FIS and poor sleep quality is mediated by psychological distress(56). This suggests the association between FIS and sleep exists within the context of other health variables, especially mental illnesses.

\section{Cardiovascular}

\section{Dyslipidemia}

Seven manuscripts studied the association between FIS and hyperlipidemia in the USA, and six of them show a significant association(29,107-112) (Table 2). The association between FIS and hyperlipidemia was shown among diabetic adults(111), low-income adults(109), and the general public $(107,110)$, particularly in male adults(29). One paper suggested that FIS can lead to hyperlipidemia due to poor dietary choices, such as choosing to eat energy-dense foods with fewer nutrients(109). Another paper proposed that dyslipidemia is related to poor glycemic control and metabolic disorders, which is also associated with FIS(111). 
Table 2. Dyslipidemia and FIS

\begin{tabular}{|c|c|c|c|c|c|c|}
\hline Year & Authors & $\begin{array}{l}\text { FIS } \\
\text { measurement }\end{array}$ & HO measurement & $\begin{array}{l}\text { Population } \\
\text { characteristics }\end{array}$ & $\begin{array}{l}\text { Study } \\
\text { size }\end{array}$ & $\begin{array}{l}\text { Significant } \\
\text { association } \\
\text { with FIS? }\end{array}$ \\
\hline 2006 & $\begin{array}{l}\text { Holben et } \\
\text { al.(29) }\end{array}$ & USDA FSSM & Total cholesterol & $\begin{array}{l}\text { Adults in Athens, } \\
\text { Hocking, Meigs, Perry, } \\
\text { Pike, and Vinton counties } \\
\text { in Ohio }\end{array}$ & 808 & Yes \\
\hline 2008 & $\begin{array}{l}\text { Stuff et } \\
\text { al.(107) }\end{array}$ & USDA FSSM & $\begin{array}{l}\text { Self-reported survey, } \\
\text { cholesterol }\end{array}$ & $\begin{array}{l}\text { Adults in the lower } \\
\text { Mississippi Delta }\end{array}$ & 1,457 & Yes \\
\hline 2009 & $\begin{array}{l}\text { Tayie et } \\
\text { al.(108) }\end{array}$ & $\begin{array}{l}10 \text { items from } \\
\text { USDA FSSM }\end{array}$ & LDL cholesterol & $\begin{array}{l}\text { Adults across the USA in } \\
\text { NHANES }\end{array}$ & 5,400 & No \\
\hline 2009 & $\begin{array}{l}\text { Tayie et } \\
\text { al.(108) }\end{array}$ & $\begin{array}{l}10 \text { items from } \\
\text { USDA FSSM }\end{array}$ & Total cholesterol & $\begin{array}{l}\text { Adults across the USA in } \\
\text { NHANES }\end{array}$ & 5,400 & No \\
\hline 2010 & $\begin{array}{l}\text { Seligman et } \\
\text { al.(109) }\end{array}$ & USDA FSSM & $\begin{array}{l}\text { Total cholesterol, } \\
\text { self-reported and } \\
\text { clinical diagnoses }\end{array}$ & $\begin{array}{l}\text { Low-income adults in the } \\
\text { USA in NHANES }\end{array}$ & 1,930 & Yes \\
\hline 2013 & Ford(110) & USDA FSSM & HDL cholesterol & $\begin{array}{l}\text { Adults across the USA in } \\
\text { NHANES }\end{array}$ & 10,455 & Yes \\
\hline 2015 & $\begin{array}{l}\text { Berkowitz } \\
\text { et al.(111) }\end{array}$ & USDA FSSM & LDL cholesterol & $\begin{array}{l}\text { Adults in MA receiving } \\
\text { treatment for diabetes } \\
\text { mellitus }\end{array}$ & 411 & Yes \\
\hline 2015 & $\begin{array}{l}\text { Moreno et } \\
\text { al.(112) }\end{array}$ & $\begin{array}{l}6 \text { items from } \\
\text { USDA FSSM }\end{array}$ & LDL cholesterol & Latinos with diabetes & 250 & Yes \\
\hline
\end{tabular}

LDL: Low-Density Lipoprotein

HDL: High-Density Lipoprotein

\section{Hypertension}

Twelve manuscripts studied the association between FIS and hypertension(29,61,63,107,109116), and seven manuscripts showed a significant association (Table S2-5). The association between FIS and hypertension was demonstrated in minorities(63,115), pregnant women(113), low-income adults(109,113), older adults(116), and the general public(107,110). The association was not found in some adult populations such as Mexican immigrants(61) and adults living in certain parts of Massachusetts(29) and Ohio(111). One manuscript suggested that these results are mixed due to hypertension's sensitivity to medication adherence rather than $\operatorname{diet}(109)$. Another suggested that, unlike hyperlipidemia, hypertension is not reliant on the same metabolic pathways that are affected by FIS(111). 


\section{Other Cardiovascular Health Outcomes}

There were three manuscripts that studied the association between FIS and anemia $(29,61,113,117)$, and only one of the papers shows a significant association between the two variables (Table S2-6). This association was found in children of low-income families,(117) but not adults(29,113). Younger children were more likely to be anemic than older children(117). The mechanism by which FIS may lead to anemia is unknown. However, in the manuscript that found a significant association between FIS and anemia, the authors acknowledge that the families that were food insecure had a family history of anemia(117).

Two manuscripts showed significant association between FIS and cardiovascular disease(107,110). This association was found in the general public(107,110), particularly in adults age 30-59.(110) Both manuscripts used previous diagnoses of cardiovascular disease as a major health outcome associated with FIS. Furthermore one manuscript concluded that very low FIS is correlated with increased predicted ten-year cardiovascular disease risk(110).

Two studies showed significant association between FIS and risk for heart attack. Both papers showed that adults across the USA who are FIS have higher levels of C-reactive protein, a marker that is caused by inflammation in the arteries, which leads to a higher risk of heart attack $(110,118)$.

One paper showed significant association between FIS and peripheral artery disease (PAD) in older adults(119). Peripheral artery disease was measured through the ankle-brachial index. The mechanism by which FIS can lead to PAD is unknown, but the authors suggested that a low-nutrient diet causes inflammation in endothelial walls, which may damage arteries(119). 
One paper showed significant association between FIS and previous diagnosis of stroke(107). The mechanism between FIS and stroke is unknown and was not discussed in the paper.

It should also be mentioned that there are reviews in the literature that conclude that there is a significant association between FIS and the following cardiovascular disorders: hyperlipidemia(32,36,40,43), hypertension(32,40,43), childhood iron deficiency anemia(33,47), and risk for cardiac disease(33). Though these studies conclude that there is a positive association between FIS and the health outcome, this systematic review shows that the results are mixed, particularly amongst manuscripts that discussed hypertension and anemia. Therefore, it is unclear whether there is a positive association or no association between FIS with hypertension and anemia.

\section{Endocrine}

\section{Body Mass Index}

We found 37 manuscripts that directly measured the association between FIS and body mass index $(\mathrm{BMI})(30,54,58,61,63,67,71,83-85,87,107,108,112-116,118,120-137)$. Only 18 manuscripts report a statistically significant association (Table 3). The diverse group of results merits careful inspection of the different methodologies used in the manuscripts.

In this group of studies, a subset (25/37) involve designs where researchers measure the weight and height of the patients, a subset (3/37) where the parameters were extracted from clinical documents, and another (9/37) where height and weight are self-reported by patients. For the studies where researchers measure the height and weight, 11/25 studies found a significant association; while the selfreport methodology yielded 6/9 studies with significant association. One concern of the self-report measurements is that response bias may make it more likely for these studies to go towards a conclusion for positive FIS association, and this concern is based on the percentage of papers that show significant 
association. A difference of $6 / 9$ versus 11/25 suggests that the self-reported papers are more likely to have report-bias that results in obtaining an association between FIS and BMI; however, this is still a distribution with a high probability that the null hypothesis (no difference in likelihood of observing a positive FIS association) is true $(p=0.20)$. These studies are also very diverse in the populations' studies. It's also possible that the difference in conclusions arise from the fact that the studies present data on diverse populations (children, women, patients above 50 years old, women, underserved populations, etc.) and that the association is complex.

Table 3. BMI and FIS

\begin{tabular}{|c|c|c|c|c|c|c|}
\hline Year & Authors & FIS measurement & HO measurement & $\begin{array}{l}\text { Population } \\
\text { characteristics }\end{array}$ & $\begin{array}{l}\text { Study } \\
\text { size }\end{array}$ & $\begin{array}{l}\text { Significant } \\
\text { association } \\
\text { with FIS? }\end{array}$ \\
\hline 1999 & $\begin{array}{l}\text { Olson, C. } \\
\text { M.(30) }\end{array}$ & $\begin{array}{l}\text { Radimer/Cornell } \\
\text { questionnaire }\end{array}$ & $\begin{array}{l}\text { BMI measured by } \\
\text { researchers }\end{array}$ & $\begin{array}{l}\text { Childbearing-age } \\
\text { women from upstate } \\
\text { New York }\end{array}$ & 193 & Yes \\
\hline 2003 & $\begin{array}{l}\text { Sharkey et } \\
\text { al.(67) }\end{array}$ & $\begin{array}{l}4 \text { custom } \\
\text { questions }\end{array}$ & $\begin{array}{l}\text { BMI measured by } \\
\text { researchers }\end{array}$ & $\begin{array}{l}\text { Senior women who } \\
\text { receive home- } \\
\text { delivered meals }\end{array}$ & 281 & No \\
\hline 2004 & $\begin{array}{l}\text { Kaiser et } \\
\text { al.(120) }\end{array}$ & USDA FSSM & $\begin{array}{l}\text { BMI measured by } \\
\text { researchers }\end{array}$ & $\begin{array}{l}\text { Low-income Latino } \\
\text { women }\end{array}$ & 559 & Yes \\
\hline 2005 & $\begin{array}{l}\text { Jyoti et } \\
\text { al.(121) }\end{array}$ & USDA FSSM & $\begin{array}{l}\text { BMI measured by } \\
\text { researchers }\end{array}$ & $\begin{array}{l}\text { Children from ECLS- } \\
\text { K Database }\end{array}$ & 10,869 & No \\
\hline 2006 & $\begin{array}{l}\text { Whitaker et } \\
\text { al.(122) }\end{array}$ & USDA FSSM & $\begin{array}{l}\text { BMI measured by } \\
\text { researchers }\end{array}$ & $\begin{array}{l}\text { Study cohort of pre- } \\
\text { school children across } \\
\text { USA }\end{array}$ & 2452 & No \\
\hline 2006 & $\begin{array}{l}\text { Rose et } \\
\text { al.(123) }\end{array}$ & USDA FSSM & $\begin{array}{l}\text { BMI measured by } \\
\text { researchers }\end{array}$ & $\begin{array}{l}\text { Children from ECLS- } \\
\text { K Database }\end{array}$ & 16,889 & Yes \\
\hline 2006 & $\begin{array}{l}\text { Jones et } \\
\text { al.(121) }\end{array}$ & USDA FSSM & $\begin{array}{l}\text { Self-reported height } \\
\text { and weight }\end{array}$ & $\begin{array}{l}\text { Pregnant women } \\
\text { across USA in PSID }\end{array}$ & 5,503 & Yes \\
\hline 2007 & $\begin{array}{l}\text { Weigel et } \\
\text { al.(61) }\end{array}$ & USDA FSSM & $\begin{array}{l}\text { BMI measured by } \\
\text { researchers }\end{array}$ & $\begin{array}{l}\text { Mexican immigrants } \\
\text { in the USA Farm } \\
\text { workers. }\end{array}$ & 100 & No \\
\hline 2007 & $\begin{array}{l}\text { Martin et } \\
\text { al.(125) }\end{array}$ & USDA FSSM & $\begin{array}{l}\text { BMI measured by } \\
\text { researchers }\end{array}$ & $\begin{array}{l}\text { Parents and children } \\
\text { from Connecticut }\end{array}$ & 412 & Yes \\
\hline 2007 & Kim et al.(71) & USDA FSSM & $\begin{array}{l}\text { Self-reported height } \\
\text { and weight }\end{array}$ & $\begin{array}{l}\text { Adults between } 51-61 \\
\text { years old from across } \\
\text { the USA }\end{array}$ & 9,481 & No \\
\hline 2007 & $\begin{array}{l}\text { Jones, S. J. et } \\
\text { al.(126) }\end{array}$ & USDA FSSM & $\begin{array}{l}\text { Self-reported height } \\
\text { and weight }\end{array}$ & $\begin{array}{l}\text { Adult women across } \\
\text { USA in PSID }\end{array}$ & 5,595 & No \\
\hline 2008 & $\begin{array}{l}\text { Stuff et } \\
\text { al.(107) }\end{array}$ & USDA FSSM & $\begin{array}{l}\text { Self-reported height } \\
\text { and weight }\end{array}$ & $\begin{array}{l}\text { Adults in Lower } \\
\text { Mississippi Delta }\end{array}$ & 1,457 & Yes \\
\hline
\end{tabular}




\begin{tabular}{|c|c|c|c|c|c|c|}
\hline 2009 & Gao et al.(63) & USDA FSSM & $\begin{array}{l}\text { BMI measured by } \\
\text { researchers }\end{array}$ & $\begin{array}{l}\text { Puerto Rican } \\
\text { community in Boston }\end{array}$ & 1,358 & No \\
\hline 2009 & $\begin{array}{l}\text { Widome et } \\
\text { al.(127) }\end{array}$ & $\begin{array}{l}2 \text { questions from } \\
\text { USDA FSSM }\end{array}$ & $\begin{array}{l}\text { BMI measured by } \\
\text { researchers }\end{array}$ & $\begin{array}{l}\text { High school students } \\
\text { in Minneapolis }\end{array}$ & 4,746 & No \\
\hline 2009 & $\begin{array}{l}\text { Tayie et } \\
\text { al.(108) }\end{array}$ & $\begin{array}{l}10 \text { items from } \\
\text { USDA FSSM }\end{array}$ & $\begin{array}{l}\text { BMI measured by } \\
\text { researchers }\end{array}$ & $\begin{array}{l}\text { Adults across the } \\
\text { USA in NHANES }\end{array}$ & 5,400 & Yes \\
\hline 2010 & $\begin{array}{l}\text { Laraia, B. } \\
\text { A.(113) }\end{array}$ & USDA FSSM & $\begin{array}{l}\text { Pregravid BMI self- } \\
\text { reported height and } \\
\text { weight }\end{array}$ & $\begin{array}{l}\text { Pregnant women in } \\
\text { PIN cohort }\end{array}$ & 810 & Yes \\
\hline 2010 & $\begin{array}{l}\text { Hendrickson } \\
\text { et al.(128) }\end{array}$ & USDA FSSM & $\begin{array}{l}\text { Review of hospital } \\
\text { documents }\end{array}$ & $\begin{array}{l}\text { Asthma children } \\
\text { patients visiting ED }\end{array}$ & 127 & No \\
\hline 2010 & $\begin{array}{l}\text { Sullivan et } \\
\text { al.(54) }\end{array}$ & USDA FSSM & $\begin{array}{l}\text { Self-reported height } \\
\text { and weight }\end{array}$ & Boston ED patients & 520 & Yes \\
\hline 2011 & $\begin{array}{l}\text { Karnik et } \\
\text { al.(129) }\end{array}$ & $\begin{array}{l}2 \text { custom } \\
\text { questions }\end{array}$ & $\begin{array}{l}\text { BMI measured by } \\
\text { physician }\end{array}$ & $\begin{array}{l}\text { Primary care clinic } \\
\text { patients }\end{array}$ & 558 & Yes \\
\hline 2012 & $\begin{array}{l}\text { Gowda et } \\
\text { al.(118) }\end{array}$ & USDA FSSM & $\begin{array}{l}\text { BMI measured by } \\
\text { researchers }\end{array}$ & NHANES database & 12,191 & Yes \\
\hline 2013 & \begin{tabular}{|l|} 
Robaina et \\
al.(130)
\end{tabular} & USDA FSSM & $\begin{array}{l}\text { BMI measured by } \\
\text { researchers }\end{array}$ & $\begin{array}{l}\text { Food Pantry clients in } \\
\text { Connecticut }\end{array}$ & 212 & No \\
\hline 2014 & $\begin{array}{l}\text { Sirotin, N. et } \\
\text { al.(131) }\end{array}$ & USDA FSSM & $\begin{array}{l}\text { BMI measured by } \\
\text { researchers }\end{array}$ & $\begin{array}{l}\text { HIV infected women } \\
\text { in the Bronx }\end{array}$ & 350 & Yes \\
\hline 2015 & $\begin{array}{l}\text { Asfour, L. et } \\
\text { al.(132) }\end{array}$ & $\begin{array}{l}\text { CDC Prevention } \\
\text { Survey }\end{array}$ & $\begin{array}{l}\text { BMI measured by } \\
\text { researchers }\end{array}$ & $\begin{array}{l}\text { 2-5-year-old in } \\
\text { Miami }\end{array}$ & 1,211 & No \\
\hline 2015 & $\begin{array}{l}\text { Cheung et } \\
\text { al.(133) }\end{array}$ & $\begin{array}{l}2 \text { custom } \\
\text { questions }\end{array}$ & $\begin{array}{l}\text { BMI measured by } \\
\text { researcher }\end{array}$ & $\begin{array}{l}\text { Patients in } \\
\text { community health } \\
\text { center in MA }\end{array}$ & 457 & Yes \\
\hline 2015 & $\begin{array}{l}\text { McCurdy et } \\
\text { al.(135) }\end{array}$ & USDA FSSM & $\begin{array}{l}\text { Self-reported height } \\
\text { and weight }\end{array}$ & $\begin{array}{l}\text { Mothers using day } \\
\text { care centers }\end{array}$ & 166 & Yes \\
\hline 2015 & $\begin{array}{l}\text { Moreno et } \\
\text { al.(112) }\end{array}$ & $\begin{array}{l}6 \text { items from } \\
\text { USDA FSSM } \\
\end{array}$ & $\begin{array}{l}\text { BMI from chart } \\
\text { reviews }\end{array}$ & Latinos with diabetes & 250 & Yes \\
\hline 2015 & $\begin{array}{l}\text { Millimet et } \\
\text { al.(134) }\end{array}$ & USDA CFSM & $\begin{array}{l}\text { BMI measured by } \\
\text { researchers and } \\
\text { assessing future } \\
\text { childhood obesity }\end{array}$ & $\begin{array}{l}\text { Children in ECLS-K } \\
\text { Database }\end{array}$ & 10,700 & No \\
\hline 2016 & \begin{tabular}{|l|} 
Sharpe et \\
al.(85)
\end{tabular} & $\begin{array}{l}6 \text { items from } \\
\text { USDA FSSM }\end{array}$ & $\begin{array}{l}\text { BMI measured by } \\
\text { researchers }\end{array}$ & $\begin{array}{l}25-50 \text {-year-old } \\
\text { women }\end{array}$ & 202 & No \\
\hline 2016 & $\begin{array}{l}\text { Bruening et } \\
\text { al.(83) }\end{array}$ & USDA FSSM & $\begin{array}{l}\text { BMI measured by } \\
\text { researchers }\end{array}$ & $\begin{array}{l}\text { College freshmen in } \\
\text { Southwestern USA }\end{array}$ & 206 & No \\
\hline 2016 & $\begin{array}{l}\text { Burke, } \\
\text { Frongillo, et } \\
\text { al.(84) }\end{array}$ & USDA FSSM & $\begin{array}{l}\text { BMI measured by } \\
\text { researchers }\end{array}$ & $\begin{array}{l}\text { Children in ECLS-K } \\
\text { Database }\end{array}$ & 15,800 & Yes \\
\hline 2017 & $\begin{array}{l}\text { Vaccaro et } \\
\text { al.(116) }\end{array}$ & USDA FSSM & $\begin{array}{l}\text { BMI measured by } \\
\text { NHANES researchers }\end{array}$ & $\begin{array}{l}\text { Patients }>55 \text { years } \\
\text { old across USA }\end{array}$ & 3,781 & Yes \\
\hline 2017 & Palar et al.(87) & USDA FSSM & $\begin{array}{l}\text { BMI measured by } \\
\text { researchers }\end{array}$ & $\begin{array}{l}\text { Patients with HIV } \\
\text { and/or T2DM in San } \\
\text { Francisco, CA }\end{array}$ & 52 & No \\
\hline 2017 & \begin{tabular}{|l|} 
Darling et \\
al.(58)
\end{tabular} & $\begin{array}{l}\text { Hager's } \\
\text { questionnaire }\end{array}$ & $\begin{array}{l}\text { BMI measured by } \\
\text { researchers }\end{array}$ & College freshmen & 983 & No \\
\hline 2017 & Kral et & 6 items from & Measured in-site by & Mothers, and their & 50 & No \\
\hline
\end{tabular}




\begin{tabular}{|l|l|l|l|l|l|l|}
\hline & al.(136) & USDA FSSM & patients themselves & $\begin{array}{l}\text { children in } \\
\text { Philadelphia, PA }\end{array}$ & & $\begin{array}{l}\text { Underserved diabetic } \\
\text { patients }\end{array}$ \\
\hline 2017 & $\begin{array}{l}\text { Shalowitz et } \\
\text { al.(137) }\end{array}$ & USDA FSSM & $\begin{array}{l}\text { Review of clinical } \\
\text { documents }\end{array}$ & 336 & No \\
\hline 2017 & $\begin{array}{l}\text { Jernigan et } \\
\text { al.(115) }\end{array}$ & $\begin{array}{l}\text { 2 items from } \\
\text { USDA FSSM }\end{array}$ & $\begin{array}{l}\text { Self-reported height } \\
\text { and weight }\end{array}$ & $\begin{array}{l}\text { Chickasaw and } \\
\text { Choctaw Nations of } \\
\text { Oklahoma }\end{array}$ & 513 & Yes \\
\hline 2017 & $\begin{array}{l}\text { Banerjee et } \\
\text { al.(114) }\end{array}$ & Custom question & $\begin{array}{l}\text { BMI measured by } \\
\text { researchers }\end{array}$ & $\begin{array}{l}\text { Adults with CKD } \\
\text { below 400\% of the } \\
\text { federal poverty line }\end{array}$ & 12,700 & No \\
\hline
\end{tabular}

ECLS-K: Early Childhood Longitudinal Program

PSID: Panel Study of Income Dynamics

PIN: Pregnancy, Infection, and Nutrition Study

CDC: Center for Disease Control

T2DM: Type 2 Diabetes Mellitus

CA: California

PA: Pennsylvania

CKD: Chronic Kidney Disease

\section{Diabetes}

We identified seventeen peer-reviewed USA articles studying the association between FIS and diabetes(29,55,61,82,107,109,111-116,137-140). Of those manuscripts, twelve of them show a significant association (Table S2-7). Articles assess both the report of a diabetes diagnosis and measurements including Hemoglobin $\mathrm{A} 1 \mathrm{C}$ and the oral glucose tolerance test (OGTT). These associations are studied in a wide group of populations including rural communities $(29,107)$, Hispanic adults(55,109,112), pregnant women(113), Native Americans(115), geriatric patients(116), adults in the general population(109), and adults with other chronic illnesses, including HIV(87). While not all studies show significant results, the mechanism underlying associations between FIS and poor diabetes control is easily conceivable, as proper diabetes management requires implementation of healthy eating patterns which may be difficult for FIS individuals(141).

The association between diabetes and FIS is of particular interest due to the extensive healthcare 
and economic implications of diabetes. Type 2 diabetes mellitus (T2DM) is known to be associated with several debilitating conditions, such as kidney disease and retinopathy(36). Economically, the estimated cost of diagnosed diabetes is $\$ 245$ billion(142).

Furthermore, studies by Seligman et al. show evidence that adults with T2DM and FIS are more likely to suffer severe hypoglycemic episodes than those with food security(138) - this is also important and worthy of future research since hypoglycemic episodes can be devastating to patients(143), and are costly to society(144).

\section{Metabolic Syndrome}

There were three manuscripts investigating the association between FIS and metabolic syndrome, and two found a significant association(107,145) (Table S2-8). Parker et al.(145) studied this association across the USA adult population using NHANES, resulting in a large study with over 9,000 entries. Stuff et al. reached a similar conclusion studying adults in Mississippi(107). Both articles use the Adult Treatment Panel III guidelines for metabolic syndrome diagnosis, considering waist circumference, triglycerides, HDL levels, blood pressure, and blood glucose.

\section{General Health}

\section{Children Anthropometric Measurements}

Seven studies explored the association between FIS and children's anthropometric measurements (Table 4). Several manuscripts showed that there was no significant association between FIS and children's height(128), weight-for-length(70,146), weight-for-age(62,78), and probability of pre-term birth(147). Although one study did find an association between proxy-reported low birth weight and FIS(51). 
Table 4. Children Anthropometric Measurements and FIS

\begin{tabular}{|c|c|c|c|c|c|c|}
\hline Year & Authors & $\begin{array}{l}\text { FIS } \\
\text { measurement }\end{array}$ & HO measurement & $\begin{array}{l}\text { Population } \\
\text { characteristic }\end{array}$ & $\begin{array}{l}\text { Study } \\
\text { Size }\end{array}$ & $\begin{array}{l}\text { Significant } \\
\text { association with } \\
\text { FIS? }\end{array}$ \\
\hline 2002 & $\begin{array}{l}\text { Weinreb et } \\
\text { al.(51) }\end{array}$ & $\begin{array}{l}\text { Custom } \\
\text { question }\end{array}$ & $\begin{array}{l}\text { Proxy-reported low- } \\
\text { birth weight }\end{array}$ & $\begin{array}{l}\text { Preschool children in } \\
\text { MA }\end{array}$ & 203 & Yes \\
\hline 2007 & $\begin{array}{l}\text { Bronte-Tinkew } \\
\text { et al.(70) }\end{array}$ & USDA FSSM & Length/Age Survey & ECLS-B & 8,693 & Yes \\
\hline 2007 & $\begin{array}{l}\text { Bronte-Tinkew } \\
\text { et al.(70) }\end{array}$ & USDA FSSM & $\begin{array}{l}\text { Weight/Length } \\
\text { survey }\end{array}$ & ECLS-B & 8,693 & Yes \\
\hline 2008 & $\begin{array}{l}\text { Rose-Jacobs et } \\
\text { al.(62) }\end{array}$ & USDA FSSM & $\begin{array}{l}\text { Weight-for-age z } \\
\text { score }\end{array}$ & $\begin{array}{l}\text { ACP clinics and ED } \\
\text { patients }\end{array}$ & 2,010 & No \\
\hline 2012 & Cook et al.(78) & USDA FSSM & Weight/age $<5 \%$ & Across USA & 41,515 & No \\
\hline 2010 & $\begin{array}{l}\text { Hendrickson et } \\
\text { al.(128) }\end{array}$ & USDA FSSM & Children's height & $\begin{array}{l}\text { Asthma children } \\
\text { patients visiting ED }\end{array}$ & 127 & No \\
\hline 2015 & $\begin{array}{l}\text { Tucker et } \\
\text { al.(147) }\end{array}$ & Not specified & Preterm birth & $\begin{array}{l}\text { Medicaid patients in } \\
\mathrm{NC}\end{array}$ & 15,428 & No \\
\hline 2016 & $\begin{array}{l}\text { Barroso et } \\
\text { al.(146) }\end{array}$ & $\begin{array}{l}2 \text { custom } \\
\text { questions }\end{array}$ & Weight-for-length & $\begin{array}{l}\text { Hispanic families from } \\
\text { Southwestern USA }\end{array}$ & 240 & No \\
\hline
\end{tabular}

ACP: Asthma Care Pathway

ECLS-B: Early Childhood Longitudinal Survey-Birth Cohort

NC: North Carolina

\section{Self-reported and Proxy-reported Health}

Our search found 16 manuscripts with data that directly compared self-reported health to FIS(64,86,112,116,148-159), from which 14 studies found a significant association between the two variables (Table S2-9). These studies included, among others, older adults(64,148,151), caregivers(149), immigrants(152), college students(156), and the general public(116). The utility of self-reported health has been demonstrated by its strong association with mortality(160-162). Benjamin et al. showed that 
self-reported health is strongly associated with death from diabetes, infectious diseases, heart disease, and other chronic conditions(163).

Similarly, seven manuscripts had data on the association between the health of the child, reported by parents or guardians, and FIS in the household(49,70,78,128,164-166); and six studies found a significant association (Table S2-10).

\section{Infectious Disease}

\section{Unsuppressed HIV (High Viral Load)}

Nine manuscripts investigated the effects of FIS on HIV viral loads(79,167-174). Most of them established HIV viral loads to be elevated and unsuppressed if the level were greater than 500 ribonucleic acid (RNA) copies/mL. All the studies established a significant correlation between FIS and an unsuppressed HIV viral load (Table 5). Multiple pathways have been proposed to explain this relationship, some of them include nutrient deficits, poor coping strategies and behaviors, psychological distress, and substance abuse $(167,174)$. Psychological and behavioral changes can lead to missed HIV clinic visits and decreased ART medication adherence. In particular, ART medication is typically taken with food for maximal processing and absorption(172,173). Therefore, HIV patients who are FIS may either take ART medication without following directed use, or they may skip taking medication altogether. 
Table 5. HIV Viral Load and FIS

\begin{tabular}{|c|c|c|c|c|c|c|}
\hline Year & Authors & FIS measurement & $\begin{array}{l}\text { HO } \\
\text { measurement }\end{array}$ & $\begin{array}{l}\text { Population } \\
\text { characteristics }\end{array}$ & \begin{tabular}{|l} 
Study \\
Size
\end{tabular} & $\begin{array}{l}\text { Significant } \\
\text { association } \\
\text { with FIS? } \\
\end{array}$ \\
\hline 2009 & $\begin{array}{l}\text { Weiser, S. D. } \\
\text { et al.(167) }\end{array}$ & USDA FSSM & $\begin{array}{l}\text { Viral Load Blood } \\
\text { Test }\end{array}$ & $\begin{array}{l}\text { Homeless HIV individuals } \\
\text { receiving ART in San } \\
\text { Francisco, CA }\end{array}$ & 104 & Yes \\
\hline 2011 & $\begin{array}{l}\text { Wang, E. A. } \\
\text { et al.(168) }\end{array}$ & $\begin{array}{l}1 \text { item from USDA } \\
\text { FSSM }\end{array}$ & \begin{tabular}{|l|} 
Viral Load Blood \\
Test
\end{tabular} & HIV veteran & 2,353 & Yes \\
\hline 2013 & $\begin{array}{l}\text { Mendoza, J. } \\
\text { A. et al.(169) }\end{array}$ & USDA FSSM & \begin{tabular}{|l|} 
Viral Load Blood \\
Test
\end{tabular} & $\begin{array}{l}\text { HIV individuals in } \\
\text { Houston, TX }\end{array}$ & 62 & Yes \\
\hline 2014 & $\begin{array}{l}\text { Kalichman, S. } \\
\text { C. et al.(79) } \\
\end{array}$ & $\begin{array}{l}\text { 4-item Coates, } \\
\text { Swindale, and } \\
\text { Bilinsky } \\
\end{array}$ & $\begin{array}{l}\text { Viral Load Blood } \\
\text { Test }\end{array}$ & $\begin{array}{l}\text { HIV individuals receiving } \\
\text { ART in Atlanta, GA }\end{array}$ & 197 & Yes \\
\hline 2015 & $\begin{array}{l}\text { Feldman, M. } \\
\text { B. et al.(170) }\end{array}$ & $\begin{array}{l}3 \text { items from } \\
\text { Adaptation to US } \\
\text { Census Current } \\
\text { Population Survey }\end{array}$ & $\begin{array}{l}\text { Viral Load Blood } \\
\text { Test }\end{array}$ & $\begin{array}{l}\text { HIV individuals in NYC } \\
\text { enrolled in a nutrition } \\
\text { service program }\end{array}$ & 2,118 & Yes \\
\hline 2015 & $\begin{array}{l}\text { Kalichman et } \\
\text { al.(171) }\end{array}$ & Custom questions & $\begin{array}{l}\text { Self-reported } \\
\text { Viral Load }\end{array}$ & $\begin{array}{l}\text { HIV individuals in } \\
\text { Atlanta, GA recruited } \\
\text { from clinical and } \\
\text { community services }\end{array}$ & 671 & Yes \\
\hline 2015 & $\begin{array}{l}\text { Kalichman et } \\
\text { al.(172) }\end{array}$ & USDA FSSM & $\begin{array}{l}\text { Viral Load from } \\
\text { medical records }\end{array}$ & $\begin{array}{l}\text { HIV adults from Atlanta, } \\
\text { GA }\end{array}$ & 418 & Yes \\
\hline 2015 & $\begin{array}{l}\text { Kalichman et } \\
\text { al.(173) }\end{array}$ & Custom questions & $\begin{array}{l}\text { Self-reported } \\
\text { Viral Load }\end{array}$ & $\begin{array}{l}\text { HIV individuals in } \\
\text { Atlanta, GA recruited } \\
\text { from clinical and } \\
\text { community services }\end{array}$ & 759 & Yes \\
\hline 2015 & $\begin{array}{l}\text { Surratt, H. L. } \\
\text { et al.(174) }\end{array}$ & 1 custom question & $\begin{array}{l}\text { Self-reported } \\
\text { Viral Load }\end{array}$ & $\begin{array}{l}\text { Documented HIV adults } \\
\text { with current ART } \\
\text { prescription }\end{array}$ & 503 & Yes \\
\hline
\end{tabular}

TX: Texas

GA: Georgia

NYC: New York City

\section{Unsuppressed HIV (Low Cluster of Differentiation 4 Count)}

A similar correlation is established with cluster of differentiation 4 (CD4) cell counts. Out of the 4 of manuscripts that study the effects of FIS on CD4 counts(168-170,172), 3 studies report a statistical correlation between FIS and low CD4 counts. These papers set the threshold for low CD4 counts as anything less than 200 cells/mL. Only one paper stated there was no significant correlation. (Table S211). 


\section{Other Infectious Disease Outcomes}

Table S2-12 in the supplementary documents shows the additional health outcomes in this section. A prospective cohort study by McMahon et al.(175) evaluated overall mortality in HIV patients versus different socioeconomic variables. The results showed a significant association between mortality and FIS. This is an unfortunate result that furthers emphasizes the importance of FIS interventions in these patients.

Lastly, there are two USA studies that explore FIS effects on other interesting infectious disease outcomes. Weigel et al. investigated the association between FIS and previous diagnosis of tuberculosis and hepatitis. The study stated that no significant association was found(61). Similarly, Naenifard et al. used the 2009-2010 NANHES survey to extract Epstein-Barr viral capsid antigen measurements in FIS populations, and found no significant association(176).

\section{Pulmonary, Musculoskeletal, and Renal Health Outcomes}

The musculoskeletal, pulmonary, and renal systems are shown in Table S2-13 of the supplementary documents. There were three manuscripts that measured the association between asthma and FIS $(61,128,177)$. Two of the studies did not find significant association between FIS and asthma in migrant seasonal farm workers(61), or children who were hospitalized for asthma(128). Only one manuscript found a significant association with asthma in kindergarteners across the USA(177). This study may have found significant results because of its large sample size. In the study that assessed hospitalized children(128), the authors mention that their convenience sample may not be representative of the whole population due to the seasonal nature of asthma.

The only paper that measured bone mineral density found a significant association between FIS and low bone mineral density in male children, which places them at risk for bone fractures(178). 
Banerjee et al.(114) investigated the renal effects of FIS by correlating it with glomerular filtration rate. Their results show that patients with CKD that experience FIS were more likely to develop end stage renal disease (ESRD) compared to non-FIS patients. Their results also show that for the non-CKD population there is no significant association between FIS and ESRD(114).

There was one manuscript that measured self-reported diagnosis of lung disease in older adults. The study found that there is no significant association between lung disease and FIS. However being food secure, and having normal waist circumference, were both protective of lung disease(116).

\section{Summary of Evidence}

The association between FIS and negative health outcomes in the USA has been investigated by at least 117 studies up until September 2017. They investigate FIS association with more than 30 health outcomes. These associations range from general perceived health to health conditions affecting several different organ systems. Behavior and cognitive function are one area that seems to have a particularly robust association to FIS. Debilitating conditions such as depression, anxiety, and sleep disorders are found to be associated with FIS in the vast majority of papers identified by this systematic review. Cardiovascular conditions such as hypertension and dyslipidemia are also associated with FIS in several reviewed manuscripts, although these associations may be influenced by comorbidity between cardiovascular conditions and diabetes. Other endocrine conditions, such as metabolic syndrome, have been identified as well. It is of note that there is not a consistent association between BMI and FIS across the literature. Though we do not hypothesize why certain authors find an association in certain populations, these mixed results suggest that further research-perhaps with a more consistent and rigorous methodology across studies - are needed to determine if there is a true association between FIS and certain healthcare outcomes. Overall, the findings of this review emphasize the value of targeted 
approaches for alleviating FIS, especially in patients suffering from cognitive and behavioral disorders. These findings will be particularly relevant for providers looking to better understand the breadth of negative outcomes associated with FIS, and also to those looking to justify FIS-based interventions.

\section{Limitations}

This study is limited mainly due to the scope of our search. The search protocol is designed to be sensitive for health outcomes, but not to be sensitive and specific for a particular health outcome. The purpose was to identify the plethora of health outcomes associated with FIS, and not to conduct a metaanalysis for each outcome. For example, our protocol is not designed to yield all the papers that investigate FIS and depression, but is designed to find as many of the psychiatric and neurologic health outcomes associated with FIS such as depression, sleep disorders, etc. Although this study does not identify every manuscript investigating FIS and a specific outcome, it elucidates the multitude of negative health consequences of FIS across several different organ systems. We did not include specific health outcomes (i.e. depression, hypertension) in the original search so that we would not bias the search towards the health outcomes known to the researchers to be associated with FIS, and to avoid an immense number of search terms and subsequent false positives. A meta-analysis for each health outcome and FIS would require a more specific search and is not in the scope of this manuscript. This study however would be a convenient starting point for those interested in conducting a meta-analysis for specific health outcomes.

Additionally, our study is not designed to arbitrate disagreements in the conclusions from different studies. In other words, we cannot offer concrete evaluation on the superiority, in risk of individual bias, of some studies over others. One main reason is that the association between FIS and a health outcome is complex and may be dependent on the population studied. Another is that many of these studies focused on convenient sample groups. 
Furthermore, it is important to reiterate that association is not the same as causation. We are reporting health outcomes that are associated with FIS, and this association may be caused by a third variable. For example, since FIS measurements do not elucidate the length of exposure to FIS, it is difficult to determine whether FIS precedes diagnosis of chronic diseases or if FIS status is acquired after living with chronic disease. Nonetheless, the association is still useful even if only as a marker for higher risk of other morbidities.

Finally, publication bias is certainly possible and a concern. Performing a meta-analysis and statistically quantifying the publication bias is complicated by the fact that different populations are studied in different manuscripts. It is worth mentioning however that our search yielded many negative results - and this shows the utility of systematic reviews.

\section{Conclusions}

A multitude of studies have shown the association between FIS and devastating negative health outcomes. This is a strong justification for screening patients for FIS because these patients are clearly at risk of developing many complications. Although we cannot determine the causality of this relationship, FIS is often a strong marker for high risk of poor physical and mental health. All these associations should also inspire further research to investigate the cost-efficiency of alleviation of FIS as a preventive medicine intervention.

\section{Author Information}

Corresponding Author: Daniel J. Arenas

Email: Daniel.arenas@uphs.upenn.edu 


\section{Author Contributions}

Daniel J. Arenas led the project along with Sara Zhou and Arthur Thomas.

Daniel J. Arenas, Sara Zhou, Arthur Thomas, and Gilberto Vilá-Arroyo designed the systematic review methodology.

All authors participated in the systematic review and edited the paper.

Sara Zhou and Arthur Thomas contributed equally to this work and their order was chosen randomly.

\section{Acknowledgments}

Daniel J. Arenas would like to thank the Gamble Scholarship for support.

No other sources of funding went towards this work.

\section{References}

1. Connolly V, Unwin N, Sherriff P, Bilous R, Kelly W. Diabetes prevalence and socioeconomic status: a population based study showing increased prevalence of type 2 diabetes mellitus in deprived areas. J Epidemiol Community Health. 2000;54(3):173-177.

2. Hertz RP, Unger AN, Cornell JA, Saunders E. Racial disparities in hypertension prevalence, awareness, and management. Arch Intern Med. 2005;165(18):2098-2104.

3. Egan BM, Zhao Y, Axon RN. US trends in prevalence, awareness, treatment, and control of hypertension, 1988-2008. Jama. 2010;303(20):2043-2050.

4. Buys DR, Howard VJ, McClure LA, Buys KC, Sawyer P, Allman RM, et al. Association between neighborhood disadvantage and hypertension prevalence, awareness, treatment, and control in older adults: results from the University of Alabama at Birmingham Study of Aging. Am J Public Health Ajph [Internet]. 2015 [cited 2017 Aug 24]; Available from: https://ajph.aphapublications.org/doi/full/10.2105/AJPH.2014.302048

5. Mensah GA, Mokdad AH, Ford ES, Greenlund KJ, Croft JB. State of disparities in cardiovascular health in the United States. Circulation. 2005;111(10):1233-1241.

6. Control C for D, (CDC P, others. Vital signs: prevalence, treatment, and control of high levels of low-density lipoprotein cholesterol-United States, 1999-2002 and 2005-200. MMWR Morb Mortal Wkly Rep. 2011;60(4):109.

7. Rodriguez CJ, Daviglus ML, Swett K, González HM, Gallo LC, Wassertheil-Smoller S, et al. Dyslipidemia patterns among Hispanics/Latinos of diverse background in the United States. Am J Med. 2014;127(12):1186-1194. 
8. Thomas PA. Racial and ethnic differences in osteoporosis. J Am Acad Orthop Surg. 2007;15:S26S30.

9. Navarro MC, Sosa M, Saavedra P, Lainez P, Marrero M, Torres M, et al. Poverty is a risk factor for osteoporotic fractures. Osteoporos Int. 2009;20(3):393-398.

10. Riolo SA, Nguyen TA, Greden JF, King CA. Prevalence of depression by race/ethnicity: findings from the National Health and Nutrition Examination Survey III. Am J Public Health. 2005;95(6):998-1000.

11. Lorant V, Croux C, Weich S, Deliège D, Mackenbach J, Ansseau M. Depression and socioeconomic risk factors: 7-year longitudinal population study. Br J Psychiatry. 2007;190(4):293298.

12. Choi AI, Rodriguez RA, Bacchetti P, Bertenthal D, Hernandez GT, O'Hare AM. White/black racial differences in risk of end-stage renal disease and death. Am J Med. 2009;122(7):672-678.

13. Young BA. The interaction of race, poverty, and CKD. Am J Kidney Dis Off J Natl Kidney Found. 2010;55(6):977.

14. Crews DC, Charles RF, Evans MK, Zonderman AB, Powe NR. Poverty, race, and CKD in a racially and socioeconomically diverse urban population. Am J Kidney Dis. 2010;55(6):9921000 .

15. Anderson SG, Malipatil NS, Roberts H, Dunn G, Heald AH. Socioeconomic deprivation independently predicts symptomatic painful diabetic neuropathy in type 1 diabetes. Prim Care Diabetes. 2014;8(1):65-69.

16. Liao Y, Greenlund KJ, Croft JB, Keenan NL, Giles WH. Factors explaining excess stroke prevalence in the US Stroke Belt. Stroke. 2009;40(10):3336-3341.

17. Roux AVD, Merkin SS, Arnett D, Chambless L, Massing M, Nieto FJ, et al. Neighborhood of residence and incidence of coronary heart disease. N Engl J Med. 2001;345(2):99-106.

18. Lindenauer PK, Lagu T, Rothberg MB, Avrunin J, Pekow PS, Wang Y, et al. Income inequality and 30 day outcomes after acute myocardial infarction, heart failure, and pneumonia: retrospective cohort study. Bmj. 2013;346:f521.

19. Borrell LN, Diez Roux AV, Rose K, Catellier D, Clark BL. Neighbourhood characteristics and mortality in the Atherosclerosis Risk in Communities Study. Int J Epidemiol. 2004;33(2):398407.

20. Bradley CJ, Given CW, Roberts C. Race, socioeconomic status, and breast cancer treatment and survival. J Natl Cancer Inst. 2002;94(7):490-496.

21. Ward E, Jemal A, Cokkinides V, Singh GK, Cardinez C, Ghafoor A, et al. Cancer disparities by race/ethnicity and socioeconomic status. CA Cancer J Clin. 2004;54(2):78-93.

22. Sambamoorthi U, McAlpine DD. Racial, ethnic, socioeconomic, and access disparities in the use of preventive services among women. Prev Med. 2003;37(5):475-484.

23. Simpson SA, Long JA. Medical student-run health clinics: important contributors to patient care and medical education. J Gen Intern Med. 2007;22(3):352-356. 
24. AB K-KA, SONG Z, ORIOL N. The Emerging Business Models and Value Proposition of Mobile Health Clinics. 2017 Aug 23 [cited 2017 Aug 23]; Available from: https://www.researchgate.net/profile/Jennifer_Bennet/publication/291332842_The_Emerging_Bu siness_Models_and_Value_Proposition_of_Mobile_Health_Clinics/links/569fc97208aee4d26ad2 7ed9.pdf

25. Carmack HJ, Bouchelle Z, Rawlins Y, Bennet J, Hill C, Oriol NE. Mobilizing a Narrative of Generosity: Patient Experiences on an Urban Mobile Health Clinic. Commun Q. 2017;1-17.

26. Buchanan D, Witlen R. Balancing service and education: ethical management of student-run clinics. J Health Care Poor Underserved. 2006;17(3):477-485.

27. Ellett JD, Campbell JA, Gonsalves WC. Patient satisfaction in a student-run free medical clinic. Fam Med. 2010;42(1):16-18.

28. Arenas DJ, Lett LA, Klusaritz H, Teitelman AM. A Monte Carlo simulation approach for estimating the health and economic impact of interventions provided at a student-run clinic. PloS One. 2017;12(12):e0189718.

29. Holben DH, Pheley AM. Peer Reviewed: Diabetes Risk and Obesity in Food-Insecure Households in Rural Appalachian Ohio. Prev Chronic Dis. 2006;3(3).

30. Olson CM. Nutrition and health outcomes associated with food insecurity and hunger. J Nutr. 1999;129(2):521S-524S.

31. Kursmark M, Weitzman M. Recent findings concerning childhood food insecurity. Curr Opin Clin Nutr Metab Care. 2009;12(3):310-316.

32. Gundersen C, Ziliak JP. Food insecurity and health outcomes. Health Aff (Millwood). 2015;34(11):1830-1839.

33. Cook JT, Frank DA. Food security, poverty, and human development in the United States. Ann N Y Acad Sci. 2008;1136(1):193-209.

34. Wallace BC, Small K, Brodley CE, Lau J, Trikalinos TA. Deploying an interactive machine learning system in an evidence-based practice center: abstrackr. In: Proceedings of the 2nd ACM SIGHIT International Health Informatics Symposium. ACM; 2012. p. 819-824.

35. Taras H. Nutrition and student performance at school. J Sch Health. 2005;75(6):199-213.

36. Walker RJ, Williams JS, Egede LE. Influence of race, ethnicity and social determinants of health on diabetes outcomes. Am J Med Sci. 2016;351(4):366-373.

37. Althoff RR, Ametti M, Bertmann F. The role of food insecurity in developmental psychopathology. Prev Med. 2016;92:106-109.

38. Hadley C, Crooks DL. Coping and the biosocial consequences of food insecurity in the 21st century. Am J Phys Anthropol. 2012;149(S55):72-94.

39. de Pee S, Grede N, Mehra D, Bloem MW. The enabling effect of food assistance in improving adherence and/or treatment completion for antiretroviral therapy and tuberculosis treatment: a literature review. AIDS Behav. 2014;18(5):531-541. 
40. Barnard LS, Wexler DJ, DeWalt D, Berkowitz SA. Material need support interventions for diabetes prevention and control: a systematic review. Curr Diab Rep. 2015;15(2):2.

41. Chop E, Duggaraju A, Malley A, Burke V, Caldas S, Yeh PT, et al. Food insecurity, sexual risk behavior, and adherence to antiretroviral therapy among women living with HIV: A systematic review. Health Care Women Int. 2017;38(9):927-944.

42. Singer AW, Weiser SD, McCoy SI. Does food insecurity undermine adherence to antiretroviral therapy? A systematic review. AIDS Behav. 2015;19(8):1510-1526.

43. Gottlieb LM, Wing H, Adler NE. A systematic review of interventions on patients' social and economic needs. Am J Prev Med. 2017;53(5):719-729.

44. Lim YM, Song S, Song WO. Prevalence and Determinants of Overweight and Obesity in Children and Adolescents from Migrant and Seasonal Farmworker Families in the United States-A Systematic Review and Qualitative Assessment. Nutrients. 2017;9(3):188.

45. Sharkey JR. Diet and health outcomes in vulnerable populations. Ann N Y Acad Sci. 2008;1136(1):210-217.

46. Eisenmann JC, Gundersen C, Lohman BJ, Garasky S, Stewart SD. Is food insecurity related to overweight and obesity in children and adolescents? A summary of studies, 1995-2009. Obes Rev. 2011;12(5).

47. Holben DH. Are your patients hungry? An examination of food insecurity in America. Osteopath Fam Physician. 2011;3(4):134-140.

48. Ochoa A, Berge JM. Home environmental influences on childhood obesity in the Latino population: a decade review of literature. J Immigr Minor Health. 2017;19(2):430-447.

49. Casey PH, Szeto K, Lensing S, Bogle M, Weber J. Children in food-insufficient, low-income families: prevalence, health, and nutrition status. Arch Pediatr Adolesc Med. 2001;155(4):508514.

50. Holben D. Position of the American Dietetic Association: food insecurity in the United States. J Am Diet Assoc. 2010;110(9):1368-1377.

51. Weinreb L, Wehler C, Perloff J, Scott R, Hosmer D, Sagor L, et al. Hunger: its impact on children's health and mental health. Pediatrics. 2002;110(4):e41-e41.

52. Laraia BA, Siega-Riz AM, Gundersen C, Dole N. Psychosocial factors and socioeconomic indicators are associated with household food insecurity among pregnant women. J Nutr. 2006;136(1):177-182.

53. Borders AE, Wolfe K, Qadir S, Kim K-Y, Holl J, Grobman W. Racial/ethnic differences in selfreported and biologic measures of chronic stress in pregnancy. J Perinatol. 2015;35(8):580-584.

54. Sullivan AF, Clark S, Pallin DJ, Camargo CA. Food security, health, and medication expenditures of emergency department patients. J Emerg Med. 2010;38(4):524-528.

55. Fitzgerald N, Hromi-Fiedler A, Segura-Pérez S, Pérez-Escamilla R. Food insecurity is related to increased risk of type 2 diabetes among Latinas. Ethn Dis. 2011;21(3):328. 
56. Bermúdez-Millán A, Pérez-Escamilla R, Segura-Pérez S, Damio G, Chhabra J, Osborn CY, et al. Psychological distress mediates the association between food insecurity and suboptimal sleep quality in Latinos with type 2 diabetes mellitus. J Nutr. 2016;146(10):2051-2057.

57. Becerra BJ, Sis-Medina RC, Reyes A, Becerra MB. Peer Reviewed: Association Between Food Insecurity and Serious Psychological Distress Among Hispanic Adults Living in Poverty. Prev Chronic Dis. 2015;12.

58. Darling KE, Fahrenkamp AJ, Wilson SM, D'Auria AL, Sato AF. Physical and mental health outcomes associated with prior food insecurity among young adults. J Health Psychol. 2017;22(5):572-581.

59. Payne-Sturges DC, Tjaden A, Caldeira KM, Vincent KB, Arria AM. Student Hunger on Campus: Food Insecurity Among College Students and Implications for Academic Institutions. Am J Health Promot. 2017;0890117117719620.

60. Greenberg PE, Sisitsky T, Kessler RC, Finkelstein SN, Berndt ER, Davidson JR, et al. The economic burden of anxiety disorders in the 1990s. J Clin Psychiatry. 1999;

61. Weigel MM, Armijos RX, Hall YP, Ramirez Y, Orozco R. The household food insecurity and health outcomes of US-Mexico border migrant and seasonal farmworkers. J Immigr Minor Health. 2007;9(3):157-169.

62. Rose-Jacobs R, Black MM, Casey PH, Cook JT, Cutts DB, Chilton M, et al. Household food insecurity: associations with at-risk infant and toddler development. Pediatrics. 2008;121(1):6572 .

63. Gao X, Scott T, Falcon LM, Wilde PE, Tucker KL. Food insecurity and cognitive function in Puerto Rican adults. Am J Clin Nutr. 2009;89(4):1197-1203.

64. Vaudin A, Sahyoun NR. Food anxiety is associated with poor health status among recently hospital-discharged older adults. J Nutr Gerontol Geriatr. 2015;34(2):245-262.

65. Wong JC, Scott T, Wilde P, Li Y-G, Tucker KL, Gao X. Food Insecurity Is Associated with Subsequent Cognitive Decline in the Boston Puerto Rican Health Study-3. J Nutr. 2016;146(9):1740-1745.

66. Johnson AD, Markowitz AJ. Associations Between Household Food Insecurity in Early Childhood and Children's Kindergarten Skills. Child Dev. 2017;

67. Sharkey JR. Risk and presence of food insufficiency are associated with low nutrient intakes and multimorbidity among homebound older women who receive home-delivered meals. J Nutr. 2003;133(11):3485-3491.

68. Stuff JE, Casey PH, Szeto KL, Gossett JM, Robbins JM, Simpson PM, et al. Household food insecurity is associated with adult health status. J Nutr. 2004;134(9):2330-2335.

69. Heflin CM, Siefert K, Williams DR. Food insufficiency and women's mental health: findings from a 3-year panel of welfare recipients. Soc Sci Med. 2005;61(9):1971-1982.

70. Bronte-Tinkew J, Zaslow M, Capps R, Horowitz A, McNamara M. Food insecurity works through depression, parenting, and infant feeding to influence overweight and health in toddlers. J Nutr. 2007;137(9):2160-2165. 
71. Kim K, Frongillo EA. Participation in food assistance programs modifies the relation of food insecurity with weight and depression in elders. J Nutr. 2007;137(4):1005-1010.

72. Harrison PA, Sidebottom AC. Systematic prenatal screening for psychosocial risks. J Health Care Poor Underserved. 2008;19(1):258-276.

73. Hromi-Fiedler A, Bermúdez-Millán A, Segura-Pérez S, Pérez-Escamilla R. Household food insecurity is associated with depressive symptoms among low-income pregnant Latinas. Matern Child Nutr. 2011;7(4):421-430.

74. Johnson CM, Sharkey JR, Dean WR. Indicators of material hardship and depressive symptoms among homebound older adults living in North Carolina. J Nutr Gerontol Geriatr. 2011;30(2):154-168.

75. Vogenthaler NS, Hadley C, Rodriguez AE, Valverde EE, Del Rio C, Metsch LR. Depressive symptoms and food insufficiency among HIV-infected crack users in Atlanta and Miami. AIDS Behav. 2011;15(7):1520-1526.

76. Waitzkin H, Getrich C, Heying S, Rodríguez L, Parmar A, Willging C, et al. Promotoras as mental health practitioners in primary care: a multi-method study of an intervention to address contextual sources of depression. J Community Health. 2011;36(2):316-331.

77. Black MM, Quigg AM, Cook J, Casey PH, Cutts DB, Chilton M, et al. WIC participation and attenuation of stress-related child health risks of household food insecurity and caregiver depressive symptoms. Arch Pediatr Adolesc Med. 2012;166(5):444-451.

78. Cook JT, Black M, Chilton M, Cutts D, Ettinger de Cuba S, Heeren TC, et al. Are Food Insecurity's Health Impacts Underestimated in the US Population? Marginal Food Security Also Predicts Adverse Health Outcomes in Young US Children and Mothers-. Adv Nutr. 2013;4(1):51-61.

79. Kalichman SC, Grebler T, Amaral CM, McKerney M, White D, Kalichman MO, et al. Food insecurity and antiretroviral adherence among HIV positive adults who drink alcohol. J Behav Med. 2014;37(5):1009-1018.

80. Kapulsky L, Tang AM, Forrester JE. Food insecurity, depression, and social support in HIVinfected Hispanic individuals. J Immigr Minor Health. 2015;17(2):408-413.

81. Leung CW, Epel ES, Willett WC, Rimm EB, Laraia BA. Household Food Insecurity Is Positively Associated with Depression among Low-Income Supplemental Nutrition Assistance Program Participants and Income-Eligible Nonparticipants1-3. J Nutr. 2014;145(3):622-627.

82. Palar K, Kushel M, Frongillo EA, Riley ED, Grede N, Bangsberg D, et al. Food insecurity is longitudinally associated with depressive symptoms among homeless and marginally-housed individuals living with HIV. AIDS Behav. 2015;19(8):1527-1534.

83. Bruening M, Brennhofer S, van Woerden I, Todd M, Laska M. Factors related to the high rates of food insecurity among diverse, urban college freshmen. J Acad Nutr Diet. 2016;116(9):14501457.

84. Burke MP, Martini LH, Çayır E, Hartline-Grafton HL, Meade RL. Severity of Household Food Insecurity Is Positively Associated with Mental Disorders among Children and Adolescents in the United States-. J Nutr. 2016;146(10):2019-2026. 
85. Sharpe PA, Whitaker K, Alia KA, Wilcox S, Hutto B. Dietary Intake, Behaviors and Psychosocial Factors Among Women from Food-Secure and Food-Insecure Households in the United States. Ethn Dis. 2016;26(2):139-146.

86. Sun J, Knowles M, Patel F, Frank DA, Heeren TC, Chilton M. Childhood adversity and adult reports of food insecurity among households with children. Am J Prev Med. 2016;50(5):561-572.

87. Palar K, Napoles T, Hufstedler LL, Seligman H, Hecht FM, Madsen K, et al. Comprehensive and Medically Appropriate Food Support Is Associated with Improved HIV and Diabetes Health. J Urban Health. 2017;94(1):87-99.

88. Radloff LS. The CES-D scale: A self-report depression scale for research in the general population. Appl Psychol Meas. 1977;1(3):385-401.

89. Gotlib IH, Cane DB. Self-report assessment of depression and anxiety. 1989;

90. Spitzer RL, Kroenke K, Williams JB, Group PHQPCS. Validation and utility of a self-report version of PRIME-MD: the PHQ primary care study. Jama. 1999;282(18):1737-1744.

91. Kroenke K, Spitzer RL. The PHQ-9: a new depression diagnostic and severity measure. Psychiatr Ann. 2002;32(9):509-515.

92. SCALE GD. Geriatric Depression Scale. Arch Intern Med. 1997;

93. Brink TL, Yesavage JA, Lum O. Geriatric depression scale. Evid-Based Diagn Handb Clin Predict Rules. 2013;297.

94. Crawford JR, Henry JD. The Depression Anxiety Stress Scales (DASS): Normative data and latent structure in a large non-clinical sample. Br J Clin Psychol. 2003;42(2):111-131.

95. Greenberg PE, Kessler RC, Birnbaum HG, Leong SA, Lowe SW, Berglund PA, et al. The economic burden of depression in the United States: how did it change between 1990 and 2000? J Clin Psychiatry. 2003;64(12):1465-1475.

96. Riihimäki K, Vuorilehto M, Melartin T, Haukka J, Isometsä E. Incidence and predictors of suicide attempts among primary-care patients with depressive disorders: a 5-year prospective study. Psychol Med. 2014;44(2):291-302.

97. Tollefson GD, Souetre EJ, Thomander L, Potvin JH. Comorbid anxious signs and symptoms in major depression: impact on functional work capacity and comparative treatment outcomes. Int Clin Psychopharmacol. 1993;

98. Cole MG, Dendukuri N. Risk factors for depression among elderly community subjects: a systematic review and meta-analysis. Am J Psychiatry. 2003;160(6):1147-1156.

99. Gurland BJ, Wilder DE, Berkman C. Depression and disability in the elderly: reciprocal relations and changes with age. Int J Geriatr Psychiatry. 1988;3(3):163-179.

100. Bonari L, Pinto N, Ahn E, Einarson A, Steiner M, Koren G. Perinatal risks of untreated depression during pregnancy. Can J Psychiatry. 2004;49(11):726-735. 
101. O'Malley JA, Klett BM, Klein MD, Inman N, Beck AF. Revealing the prevalence and consequences of food insecurity in children with epilepsy. J Community Health. 2017;42(6):1213-1219.

102. Grandner MA, Petrov MER, Rattanaumpawan P, Jackson N, Platt A, Patel NP. Sleep symptoms, race/ethnicity, and socioeconomic position. J Clin Sleep Med JCSM Off Publ Am Acad Sleep Med. 2013;9(9):897.

103. Whinnery J, Jackson N, Rattanaumpawan P, Grandner MA. Short and long sleep duration associated with race/ethnicity, sociodemographics, and socioeconomic position. Sleep. 2014;37(3):601-611.

104. Widome R, Jensen A, Bangerter A, Fu SS. Food insecurity among veterans of the US wars in Iraq and Afghanistan. Public Health Nutr. 2014;18(5):844-849.

105. Widome R, Jensen A, Fu SS. Socioeconomic disparities in sleep duration among veterans of the US wars in Iraq and Afghanistan. Am J Public Health. 2015;105(2):e70-e74.

106. Ding M, Keiley MK, Garza KB, Duffy PA, Zizza CA. Food Insecurity Is Associated with Poor Sleep Outcomes among US Adults1-3. J Nutr. 2014;145(3):615-621.

107. Stuff JE, Casey PH, Connell CL, Champagne CM, Gossett JM, Harsha D, et al. Household food insecurity and obesity, chronic disease, and chronic disease risk factors. J Hunger Environ Nutr. 2007;1(2):43-62.

108. Tayie FA, Zizza CA. Food insecurity and dyslipidemia among adults in the United States. Prev Med. 2009;48(5):480-485.

109. Seligman HK, Laraia BA, Kushel MB. Food insecurity is associated with chronic disease among low-income NHANES participants. J Nutr. 2009;140(2):304-310.

110. Ford ES. Peer Reviewed: Food security and cardiovascular disease risk among adults in the United States: Findings from the National Health and Nutrition Examination Survey, 2003-2008. Prev Chronic Dis. 2013;10.

111. Berkowitz SA, Meigs JB, DeWalt D, Seligman HK, Barnard LS, Bright O-JM, et al. Material need insecurities, diabetes control, and care utilization: Results from the Measuring Economic iNsecurity in Diabetes (MEND) study. JAMA Intern Med. 2015;175(2):257.

112. Moreno G, Morales LS, Isiordia M, de Jaimes FN, Tseng C-H, Noguera C, et al. Latinos with diabetes and food insecurity in an agricultural community. Med Care. 2015;53(5):423.

113. Laraia BA, Siega-Riz AM, Gundersen C. Household food insecurity is associated with selfreported pregravid weight status, gestational weight gain, and pregnancy complications. J Acad Nutr Diet. 2010;110(5):692-701.

114. Banerjee T, Crews DC, Wesson DE, Dharmarajan S, Saran R, Burrows NR, et al. Food insecurity, CKD, and subsequent ESRD in US adults. Am J Kidney Dis. 2017;70(1):38-47.

115. Blue Bird Jernigan V, Wetherill MS, Hearod J, Jacob T, Salvatore AL, Cannady T, et al. Food insecurity and chronic diseases among American Indians in rural Oklahoma: The THRIVE study. Am J Public Health. 2017;107(3):441-446. 
116. Vaccaro JA, Huffman FG. Sex and Race/Ethnic Disparities in Food Security and Chronic Diseases in US Older Adults. Gerontol Geriatr Med. 2017;3:2333721417718344.

117. Weinstein JL, Martin KS, Ferris AM. Household food security varies within month and is related to childhood anemia. J Hunger Environ Nutr. 2009;4(1):48-61.

118. Gowda C, Hadley C, Aiello AE. The association between food insecurity and inflammation in the US adult population. Am J Public Health. 2012;102(8):1579-1586.

119. Redmond ML, Dong F, Goetz J, Jacobson LT, Collins TC. Food insecurity and peripheral arterial disease in older adult populations. J Nutr Health Aging. 2016;20(10):989-995.

120. Kaiser LL, Townsend MS, Melgar-Quiñonez HR, Fujii ML, Crawford PB. Choice of instrument influences relations between food insecurity and obesity in Latino women. Am J Clin Nutr. 2004;80(5):1372-1378.

121. Jyoti DF, Frongillo EA, Jones SJ. Food insecurity affects school children's academic performance, weight gain, and social skills. J Nutr. 2005;135(12):2831-2839.

122. Whitaker RC, Orzol SM. Obesity among US urban preschool children: relationships to race, ethnicity, and socioeconomic status. Arch Pediatr Adolesc Med. 2006;160(6):578-584.

123. Rose D, Bodor JN. Household food insecurity and overweight status in young school children: results from the Early Childhood Longitudinal Study. Pediatrics. 2006;117(2):464-473.

124. Jones SJ, Frongillo EA. The modifying effects of Food Stamp Program participation on the relation between food insecurity and weight change in women. J Nutr. 2006;136(4):1091-1094.

125. Martin KS, Ferris AM. Food insecurity and gender are risk factors for obesity. J Nutr Educ Behav. 2007;39(1):31-36.

126. Jones SJ, Frongillo EA. Food insecurity and subsequent weight gain in women. Public Health Nutr. 2007;10(2):145-151.

127. Widome R, Neumark-Sztainer D, Hannan PJ, Haines J, Story M. Eating when there is not enough to eat: eating behaviors and perceptions of food among food-insecure youths. Am J Public Health. 2009;99(5):822-828.

128. Hendrickson MA, O'riordan MA, Arpilleda JC, Heneghan AM. Effects of food insecurity on asthma outcomes in the pediatric emergency department. Pediatr Emerg Care. 2010;26(11):823829 .

129. Karnik A, Foster BA, Mayer V, Pratomo V, McKee D, Maher S, et al. Food insecurity and obesity in New York City primary care clinics. Med Care. 2011;49(7):658-661.

130. Robaina KA, Martin KS. Food insecurity, poor diet quality, and obesity among food pantry participants in Hartford, CT. J Nutr Educ Behav. 2013;45(2):159-164.

131. Sirotin N, Hoover DR, Shi Q, Anastos K, Weiser SD. Food insecurity with hunger is associated with obesity among HIV-infected and at risk women in Bronx, NY. PloS One. 2014;9(8):e105957. 
132. Asfour L, Natale R, Uhlhorn S, Arheart KL, Haney K, Messiah SE. Ethnicity, household food security, and Nutrition and activity patterns in families with preschool children. J Nutr Educ Behav. 2015;47(6):498-505.

133. Cheung HC, Shen A, Oo S, Tilahun H, Cohen MJ, Berkowitz SA. Peer reviewed: Food insecurity and body mass index: A longitudinal mixed methods study, Chelsea, Massachusetts, 2009-2013. Prev Chronic Dis. 2015;12.

134. Millimet DL, Roy M. Partial identification of the long-run causal effect of food security on child health. Empir Econ. 2015;48(1):83-141.

135. McCurdy K, Kisler T, Gorman KS, Metallinos-Katsaras E. Food-and health-related correlates of self-reported body mass index among low-income mothers of young children. J Nutr Educ Behav. 2015;47(3):225-233.

136. Kral TV, Chittams J, Moore RH. Relationship between food insecurity, child weight status, and parent-reported child eating and snacking behaviors. J Spec Pediatr Nurs. 2017;22(2).

137. Shalowitz MU, Eng JS, McKinney CO, Krohn J, Lapin B, Wang CH, et al. Food security is related to adult type 2 diabetes control over time in a United States safety net primary care clinic population. Nutr Diabetes. 2017;7(5):e277.

138. Seligman HK, Jacobs EA, Lopez A, Sarkar U, Tschann J, Fernandez A. Food insecurity and hypoglycemia among safety net patients with diabetes. Arch Intern Med. 2011;171(13):12041206.

139. Ding M, Wilson NL, Garza KB, Zizza CA. Undiagnosed prediabetes among food insecure adults. Am J Health Behav. 2014;38(2):225-233.

140. Seligman HK, Lyles C, Marshall MB, Prendergast K, Smith MC, Headings A, et al. A pilot food bank intervention featuring diabetes-appropriate food improved glycemic control among clients in three states. Health Aff (Millwood). 2015;34(11):1956-1963.

141. Association AD. 4. Lifestyle Management: Standards of Medical Care in Diabetes-2018. Diabetes Care. 2018;41(Supplement 1):S38-S50.

142. Control C for D, Prevention. National diabetes statistics report, 2017. Atlanta GA Cent Dis Control Prev US Dept Health Hum Serv. 2017;

143. Krinsley JS, Grover A. Severe hypoglycemia in critically ill patients: risk factors and outcomes. Crit Care Med. 2007;35(10):2262-2267.

144. Ha WC, Oh SJ, Kim JH, Lee JM, Chang SA, Sohn TS, et al. Severe hypoglycemia is a serious complication and becoming an economic burden in diabetes. Diabetes Metab J. 2012;36(4):280 284.

145. Parker ED, Widome R, Nettleton JA, Pereira MA. Food security and metabolic syndrome in US adults and adolescents: findings from the National Health and Nutrition Examination Survey, 1999-2006. Ann Epidemiol. 2010;20(5):364-370.

146. Barroso CS, Roncancio A, Moramarco MW, Hinojosa MB, Davila YR, Mendias E, et al. Food security, maternal feeding practices and child weight-for-length. Appl Nurs Res. 2016;29:31-36. 
147. Tucker CM, Berrien K, Menard MK, Herring AH, Daniels J, Rowley DL, et al. Predicting preterm birth among women screened by North Carolina's Pregnancy Medical Home Program. Matern Child Health J. 2015;19(11):2438-2452.

148. Lee JS, Frongillo EA. Understanding needs is important for assessing the impact of food assistance program participation on nutritional and health status in US elderly persons. J Nutr. 2001;131(3):765-773.

149. Cook JT, Frank DA, Berkowitz C, Black MM. Food Insecurity Is Associated with Adverse Health Outcomes among Human Infants and Toddlers 1, 2. J Nutr. 2004;134(6):1432.

150. Brown B, Noonan C, Nord M. Prevalence of food insecurity and health-associated outcomes and food characteristics of Northern Plains Indian households. J Hunger Environ Nutr. 2007;1(4):3753 .

151. Holben DH, Barnett MA, Holcomb JP. Food insecurity is associated with health status of older adults participating in the commodity supplemental food program in a rural Appalachian Ohio county. J Hunger Environ Nutr. 2007;1(2):89-99.

152. Hadley C, Galea S, Nandi V, Nandi A, Lopez G, Strongarone S, et al. Hunger and health among undocumented Mexican migrants in a US urban area. Public Health Nutr. 2008;11(2):151-158.

153. Alley DE, Soldo BJ, Pagán JA, McCabe J, Deblois M, Field SH, et al. Material resources and population health: disadvantages in health care, housing, and food among adults over 50 years of age. Am J Public Health. 2009;99(S3):S693-S701.

154. Baggett TP, Singer DE, Rao SR, O’Connell JJ, Bharel M, Rigotti NA. Food insufficiency and health services utilization in a national sample of homeless adults. J Gen Intern Med. 2011;26(6):627-634.

155. Sharkey JR, Johnson CM, Dean WR. Relationship of household food insecurity to health-related quality of life in a large sample of rural and urban women. Women Health. 2011;51(5):442-460.

156. Patton-López MM, López-Cevallos DF, Cancel-Tirado DI, Vazquez L. Prevalence and correlates of food insecurity among students attending a midsize rural university in Oregon. J Nutr Educ Behav. 2014;46(3):209-214.

157. Shanafelt A, Hearst MO, Wang Q, Nanney MS. Food insecurity and rural adolescent personal health, home, and academic environments. J Sch Health. 2016;86(6):472-480.

158. Brucker DL. The association of food insecurity with health outcomes for adults with disabilities. Disabil Health J. 2017;10(2):286-293.

159. Hatsu I, Hade E, Campa A. Food Security Status is Related to Mental Health Quality of Life Among Persons Living with HIV. AIDS Behav. 2017;21(3):745-753.

160. McGee DL, Liao Y, Cao G, Cooper RS. Self-reported health status and mortality in a multiethnic US cohort. Am J Epidemiol. 1999;149(1):41-46.

161. Franks P, Gold MR, Fiscella K. Sociodemographics, self-rated health, and mortality in the US. Soc Sci Med. 2003;56(12):2505-2514. 
162. DeSalvo KB, Bloser N, Reynolds K, He J, Muntner P. Mortality prediction with a single general self-rated health question. J Gen Intern Med. 2006;21(3):267-275.

163. Benjamins MR, Hummer RA, Eberstein IW, Nam CB. Self-reported health and adult mortality risk: an analysis of cause-specific mortality. Soc Sci Med. 2004;59(6):1297-1306.

164. Gundersen C, Kreider B. Bounding the effects of food insecurity on children's health outcomes. J Health Econ. 2009;28(5):971-983.

165. Yoo JP, Slack KS, Holl JL. Material hardship and the physical health of school-aged children in low-income households. Am J Public Health. 2009;99(5):829-836.

166. Ryu J-H, Bartfeld JS. Household food insecurity during childhood and subsequent health status: the early childhood longitudinal study-kindergarten cohort. Am J Public Health. 2012;102(11):e50-e55.

167. Weiser SD, Frongillo EA, Ragland K, Hogg RS, Riley ED, Bangsberg DR. Food insecurity is associated with incomplete HIV RNA suppression among homeless and marginally housed HIVinfected individuals in San Francisco. J Gen Intern Med. 2009;24(1):14-20.

168. Wang EA, McGinnis KA, Fiellin DA, Goulet JL, Bryant K, Gibert CL, et al. Food insecurity is associated with poor virologic response among HIV-infected patients receiving antiretroviral medications. J Gen Intern Med. 2011;26(9):1012-1018.

169. Mendoza JA, Paul ME, Schwarzwald H, Liu Y, Martinez R, Nicklas TA, et al. Food insecurity, CD4 counts, and incomplete viral suppression among HIV+ patients from Texas Children's Hospital: a pilot study. AIDS Behav. 2013;17(5):1683-1687.

170. Feldman MB, Alexy ER, Thomas JA, Gambone GF, Irvine MK. The association between food insufficiency and HIV treatment outcomes in a longitudinal analysis of HIV-infected individuals in New York City. JAIDS J Acquir Immune Defic Syndr. 2015;69(3):329-337.

171. Kalichman SC, Hernandez D, Kegler C, Cherry C, Kalichman MO, Grebler T. Dimensions of poverty and health outcomes among people living with HIV infection: limited resources and competing needs. J Community Health. 2015;40(4):702-708.

172. Kalichman SC, Washington C, Grebler T, Hoyt G, Welles B, Kegler C, et al. Medication adherence and health outcomes of people living with HIV who are food insecure and prescribed antiretrovirals that should be taken with food. Infect Dis Ther. 2015;4(1):79-91.

173. Kalichman SC, Washington C, Grebler T, Hoyt G, Welles B, Kegler C, et al. Treatment outcomes among people living with HIV who are food insecure and prescribed antiretrovirals taken with food. J Prim Care Community Health. 2015;6(1):35-40.

174. Surratt HL, O’Grady CL, Levi-Minzi MA, Kurtz SP. Medication adherence challenges among HIV positive substance abusers: the role of food and housing insecurity. AIDS Care. 2015;27(3):307314.

175. McMahon J, Wanke C, Terrin N, Skinner S, Knox T. Poverty, hunger, education, and residential status impact survival in HIV. AIDS Behav. 2011;15(7):1503-1511. 
176. Naenifard H, Arif AA, Huber LR, Warner J. Risk Factors of Epstein-Barr Virus Infection Among United States Children: Data From the National Health and Nutrition Examination Survey (NHANES), 2009-2010. J Prim Care Community Health. 2015;6(3):177-181.

177. Mangini LD, Hayward MD, Dong YQ, Forman MR. Household Food Insecurity Is Associated with Childhood Asthma, 2. J Nutr. 2015;145(12):2756-2764.

178. Eicher-Miller HA, Mason AC, Weaver CM, McCabe GP, Boushey CJ. Food Insecurity Is Associated with Diet and Bone Mass Disparities in Early Adolescent Males but Not Females in the United States-3. J Nutr. 2011;141(9):1738-1745.

\section{Supplemental Information Captions}

S1: Specific terms used for searching manuscripts in each database.

S2-1 Table: Cognitive Development and FIS

S2-2 Table: Depression and FIS

S2-3 Table: Epilepsy and FIS

S2-4 Table: Sleep and FIS

S2-5 Table: Hypertension and FIS

S2-6 Table: Other Cardiovascular Outcomes and FIS

S2-7 Table: Diabetes and FIS

S2-8 Table: Metabolic Syndrome and FIS

S2-9 Table Self-reported Health and FIS

S2-10 Table: Proxy-reported Health and FIS

S2-11 Table: HIV Control (CD4 cell count) and FIS

S2-12 Table: Other Infectious Disease Outcomes and FIS

S2-13 Table: Other Organ Systems Health Outcomes and FIS 